\title{
Constructing a Climate Change Logic: An Institutional Perspective on the "Tragedy of the Commons"
}

\author{
Shahzad (Shaz) Ansari \\ Judge Business School, University of Cambridge, Cambridge CB2 1AG, United Kingdom, \\ s.ansari@jbs.cam.ac.uk \\ Frank Wijen \\ Rotterdam School of Management, Erasmus University Rotterdam, 3000 DR Rotterdam, The Netherlands, \\ fwijen@rsm.nl \\ Barbara Gray \\ Management and Organization Department, Smeal College of Business, Pennsylvania State University, Pennsylvania 16802, \\ b9g@psu.edu
}

\begin{abstract}
$\mathrm{D}$ espite increasing interest in transnational fields, transnational commons have received little attention. In contrast to economic models of commons, which argue that commons occur naturally and are prone to collective inaction and tragedy, we introduce a social constructionist account of commons. Specifically, we show that actor-level frame changes can eventually lead to the emergence of an overarching, hybrid "commons logic" at the field level. These frame shifts enable actors with different logics to reach a working consensus and avoid "tragedies of the commons." Using a longitudinal analysis of key actors' logics and frames, we tracked the evolution of the global climate change field over 40 years. We bracketed time periods demarcated by key field-configuring events, documented the different frame shifts in each time period, and identified five mechanisms (collective theorizing, issue linkage, active learning, legitimacy seeking, and catalytic amplification) that underpin how and why actors changed their frames at various points in time-enabling them to move toward greater consensus around a transnational commons logic. In conclusion, the emergence of a commons logic in a transnational field is a nonlinear process and involves satisfying three conditions: (1) key actors view their fates as being interconnected with respect to a problem issue, (2) these actors perceive their own behavior as contributing to the problem, and (3) they take collective action to address the problem. Our findings provide insights for multinational companies, nation-states, nongovernmental organizations, and other stakeholders in both conventional and unconventional commons.
\end{abstract}

Key words: institutionalization; institutional theory; governance; transnational fields; transnational commons; global commons; mechanisms; institutional logics; hybrid logics; social construction; frames; climate change; climate policy; qualitative research

History: Published online in Articles in Advance February 12, 2013.

\section{Introduction}

An increasing number of societal issues appear to fit what Garrett Hardin identified in 1968 as the "tragedy of the commons." Most conceptualizations of commons subscribe to an essentialist view, in which a commons is a large-scale environmental or social system consisting of natural or cultural resources and ideas, the benefits of which are readily accessible to all and thus prone to misuse, underinvestment, and free riding (Olson 1965, Ostrom 1990). Oceans are an example of a "conventional" commons, whereas the Internet is an "unconventional" commons (Van Laerhoven and Ostrom 2007). Examples of such commons problems include overfishing in conventional commons and digital piracy in unconventional commons. As Hardin (1968, p. 1244) noted, "Freedom in a commons brings ruin to all."
In contrast to this essentialist view, we adopt an institutional perspective on commons, where a commons is a field-level logic that is socially constructed by various actors. Although studies of social dilemmas such as commons have long fascinated economists and behavioral decision theorists (Weber et al. 2004), they have received far less attention from organizational theorists. On the rare occasions that organizational scholars have theorized about commons, their focus has remained at the national level, as exemplified by Holm's (1995) study of fisheries in Norway and Barnett and King's (2008) research on chemical firms' reputations in the United States (US). Yet many crucial commons issues warrant investigation, particularly those at the transnational level, which have drawn even less attention from organizational theorists. Transnational commons pose 
challenging managerial issues if the predicted tragedy of the commons is to be avoided, because constructions of transnational commons (e.g., the atmosphere and cyberspace) require conceptualizations that span national boundaries and transcend levels of analysis (Djelic and Quack 2008). Additionally, institutional governance processes at the transnational level dramatically increase in complexity compared with those in other fields, as no overarching governing authority exists to prescribe the rules of the game for relevant stakeholders, such as sovereign nation-states, nongovernmental organizations (NGOs), and multinational companies (MNCs) (Holder and Flessas 2008, Ostrom et al. 1999). Yet theorization about institutional processes in transnational fields, especially transnational commons, remains in its infancy (Glasbergen et al. 2007, Maguire and Hardy 2006, Wijen and Ansari 2007).

In the classic economic perspective, where commons' users are cast as rational actors (Olson 1965), commons can only be governed through centralized legislation; the imposition of full property rights through privatization (Hardin 1998); or localized voluntary communal solutions, based on trust, reciprocity, and reputation (e.g., Ostrom et al. 1999). However, in transnational commons, which span national borders and require global coordination, all of these solutions may be impossible or insufficient to address commons problems. Remarkably, and contrary to the "logic of collective action," which predicts a tendency to free ride in such projects (Olson 1965), in certain cases collective action to avert the tragedy of the commons has emerged at the transnational level (Djelic and Sahlin-Andersson 2006, Glasbergen et al. 2007, Holder and Flessas 2008, Ostrom et al. 1999, Rosenau 1992). Examples include the regulation of the global spectrum in wireless telecommunications and the Montreal Protocol for protecting the ozone layer (Krasner 1991).

An institutional lens on transnational commons allows us to understand the emergence of a commons as a social construction process in which key actors in a transnational field may eventually reach large-scale convergence around a "transnational commons logic." Conceptualizing these commons as socially constructed (Pettenger 2007) allows us to go beyond essentialist economic accounts to address unanswered questions about how affected actors can agree on and implement institutional rules and practices and discover mechanisms by which institutional agreements emerge and evolve in such conflicted and unwieldy contexts (Davis and Marquis 2005, Rao and Appadurai 2008). Consistent with notions of institutional logics (Thornton and Ocasio 2008), we contend that the construction of a transnational commons logic involves both cognitive and symbolic elements (to identify a problem) and the adoption of material practices (to address a problem). We pose three research questions that advance this institutional perspective on commons: (1) What conditions are necessary for a transnational commons logic to emerge within a field? (2) What mechanisms induce actors with conflicting logics to change their frames regarding contentious issues? (3) How do changes in actor-level frames lead to the emergence of a field-level transnational commons logic?

To answer these questions, we carried out an inductive case study to track the evolution of the climate change field. Changes in climate are widely believed to have resulted from emissions associated with industrialization, urbanization, increased mobility, and deforestation (Härtel and Pearman 2010). Because the atmosphere cannot be partitioned into privately held territories and the actions of actors may harm or benefit others, climate change represents a formidable transnational challenge (Depledge 2005, Mann and Kump 2008). Successfully averting tragedy with respect to climate change requires the cooperation of some 200 sovereign nation-states and numerous corporate and civic actors to view it as a shared concern and develop transnational solutions. The field is, however, fraught with controversy, not only about solutions to apportion responsibility for reducing emissions among different public and private actors but, more fundamentally still, about whether climate change is even a scientific certainty that warrants institutional attention and governance. Thus, perceptions that a commons problem exists in this space and that global mitigation efforts are needed have evolved slowly and remained contested.

Our analysis makes four contributions to understanding institutional processes by which commons evolve in transnational fields. First, in contrast to conventional economic accounts, which conceptualize actors as calculative and commons as natural, static, and innately public or private (e.g., Sandler 2004, Wijen and Ansari 2007), we reconceptualize the commons as a socially constructed hybrid logic, the meaning of which is subject to change as field-level frames gain and lose ascendency over time. Second, our analysis reveals three conditions necessary for a commons logic to emerge within a field. Third, abstracting from our data on climate change over a 40 -year period, we identify several process mechanisms that provoke actors with conflicting logics to change their frames to foster the gradual emergence of a commons logic. Fourth, we demonstrate how frame shifts among actors guided by different institutional logics may cumulate into nonlinear frame shifts at the field level, eventually enabling the emergence of a commons logic.

In the remainder of this paper, we first define transnational commons. Next, we review and critique economic theories of transnational commons and develop a theory of how commons are socially constructed. Then we describe our method and report and discuss our findings. We conclude with implications for the emergence of a transnational commons logic in institutional fields. 


\section{Theorizing Transnational Commons}

By institutions, we refer to "those collective frames and systems that provide stability and meaning to social behavior and social interaction and take on a rulelike status in social thought and action" (Djelic and Quack 2008, p. 300; see also Douglas 1986, pp. 46-48). Transnational fields, like other institutional fields, are richly contextualized spaces of potentially contested social positions that form around issues, where competing interests negotiate over issue interpretation and often build new linkages (Hoffman 1999, Martin 2003). For example, a field that forms around protecting the natural environment joins actors with disparate views (e.g., environmentalists and chemical manufacturers), who then occupy a common space to exert mutual influence (Hoffman 1999). In such fields, "struggles between different parties and a fair degree of institutions in the making are to be expected" (Djelic and Quack 2008, p. 303). Three types of transnational institutions can emerge: standards, regimes, and meta-organizations. Standards are "explicit, almost always written, statements that prescribe how certain actors must behave in certain situations" (Ahrne and Brunsson 2006, p. 82). Regimes are collections of nation-states that develop explicit protocols or rules for governance (e.g., the Montreal Protocol) (Young 1994). Meta-organizations (e.g., UNESCO) are voluntary associations of public and private organizations.

The development of transnational institutions involves the participation of diverse social actors at multiple levels (Djelic and Quack 2008, Wooten and Hoffman 2008). We use the term social actors broadly, as do Coleman (1974), Scott (1995), and Misangyi et al. (2008), to refer to persons (e.g., individual diplomats and scientists) or collectives of actors such as firms, NGOs, and nationstates. Widespread agreement about whether a field is a commons is unlikely initially because its boundaries and membership are frequently contested during its formative or transformational period (Garud 2008). Yet, unlike in other fields, institutional processes in transnational fields run through vertically layered institutional orders that span national borders without an overarching authority to enforce the rules of the game. An increasing number of transnational issues involve social actors from diverse countries operating at multiple levels (local, regional, and global) to create new institutional norms and an effective governance structure for the field (Djelic and Quack 2008).

Transnational commons may be tangible, such as oceans, or intangible, like the Internet. Two critical features of transnational commons stand out. First, in conceptualizing a transnational commons, actors "engage overlapping spatial and territorial formations, create overlaps between communities and interests, between states and communities" (Rao and Appadurai 2008, p. 162), and between other actors such as MNCs and
NGOs. Second, a transnational commons is characterized by the absence of an overarching authority or legal structure that generates processes to define and resolve the problems that stretch across boundaries. Consequently, institutionalization around transnational commons requires cooperation under anarchy (Axelrod 1984, Rosenau 1992) - no easy task given the inherent disincentives for collective action. We now briefly review the prominent economic arguments about commons governance and then introduce an institutional conceptualization, based on the premise that commons are socially constructed phenomena.

\section{Economic Accounts of Commons}

Conventional economic arguments about commons, premised on rational choice and methodological individualism, conceptualize commons as objectively given, innate, and naturally bonding a set of actors but also prone to misuse and underinvestment (Hardin 1968, Schelling 1978). They assume that people are selfinterested, norm-free, and opportunistic maximizers of short-term interests who, in the absence of rules limiting access and defining rights and duties, typically neglect the long-term interests of the collectivity (Blomley 2008). These traditional models of commons, such as Hardin's (1968) tragedy of the commons and Olson's (1965) logic of collective action, argue that several "classic" restraining forces preclude the possibility of devising an institutional means of voluntarily regulating commons. Economists argue that these forces make the "costs" of participation seem higher than the "benefits" of nonparticipation. Without coercive structures to induce participation, actors will shun cooperation, increasing the possibility of tragic outcomes.

Economic models identify several processes that heighten the likelihood of tragic outcomes. The best known is free riding, where some actors enjoy benefits accruing from collective effort but contribute little or nothing to the effort (Olson 1965). Alternatively, bystander apathy (i.e., avoiding action because of the availability of others to respond; see Darley and Latané 1968), conflicting interests (Levy and Egan 2003), and the lack of capabilities (Levy et al. 1993) can all block joint action. Without an external authority, these restraining forces can lead to suboptimal outcomes such as field-level stasis or, worse, the degradation of resources. Field-level prevention of such a "tragedy" then requires either enclosing the commons by delegating commons rights to a government with powers of enforcement or allocating property rights through privatization (Hardin 1998).

Despite its influence, the conventional economic approach leaves unanswered questions about why massive collective action, large-scale consensus, and governance initiatives with respect to commons problems have emerged in transnational arenas (Engels 2006, 
Glasbergen et al. 2007). More recent accounts have suggested self-regulation (Hoffman 1999) or communal solutions to commons, which allocate rights of access and use to an interdependent community of users who identify with one another and draw on trust, reciprocity, and reputation to locally craft norms that limit misuse (Ostrom 1990). However, these accounts continue to conceptualize commons as innate and natural, and few of them address transnational issues. Additionally, they fail to identify the mechanisms through which conflicting frames about the problem are reconciled, and consensus about an emerging logic becomes increasingly institutionalized.

\section{An Institutional Perspective on Commons}

Social Construction. In contrast to economic arguments, institutional theory can explain how large-scale consensus can emerge to govern transnational commons when an effective overarching authority is absent. Building on Berger and Luckman's (1968) notion of a socially constructed reality, institutional scholars argue that transnational commons are not predetermined but socially constructed phenomena, in which institutional norms and practices, rather than individualized rational choices, motivate actors' behavior (Fehr and Gintis 2007). Social problems do not exist in any objective sense but rather are "named" as a result of the collective practices that create meaning for them (Blumer 1971). Consequently, categorical distinctions (such as public versus private or collective versus individual) are not natural or essential, but are instead socially produced, varying with respect to time and location and changing as fields evolve (Holm 1995, Leblebici et al. 1991). For example, in studying the origins of art museums, DiMaggio (1991) explained how the idea that art is a public commodity came to replace the notion that art belongs only to privileged patrons.

We contend that this same social construction process applies to the notion of commons. A commons is socially constructed when actors develop a collective awareness that both a problem and a solution to it exist. What is deemed a commons is historically contingent and emerges gradually as norms and practices become institutionalized in a field. A critical moment in the social construction of a commons occurs when an environmental or social resource comes to be defined as vulnerable (e.g., scarce and finite), which then has implications for the subsequent direction of a field. For example, conceptions of oceans shifted over time-from an unlimited resource to an unclaimable transport surface, then to a claimable resource space, and finally to a field for military adventure-as political and economic structures shifted (Steinberg 2001). These shifts reproduced the ocean as a uniquely constructed space with a complex regime designed to serve a multiplicity of functions.
Rao and Appadurai (2008, p. 163) argued that "the question of what measures should be taken to protect or otherwise manage common resources are determined in part by the definitional frameworks that determine what counts as the "common." "Through the process of developing and specifying the scope, significance, and relative vulnerability of a resource, actors participate in socially constructing a commons and then, depending on the degree of consensus about their underlying logics and degree of urgency, may or may not initiate collective action to decide how the resource will be allocated or protected. Based on the discussion above, we assert that socially constructing a field as a commons involves adopting an overarching logic about the nature of the field-a commons logic.

Conflicting Logics. A core tenet of a socially constructed conceptualization of commons is the idea that actors' frames, identities, and actions are shaped by institutional logics, which provide "individuals and organizations with a set of rules and conventions-for deciding which problems get attended to, which solutions get considered and which solutions get linked to which situations" (Thornton and Ocasio 2008, p. 114). Core logics include market, corporation, profession, state, family, religion, and community (Thornton et al. 2012). To understand whether and how social actors within a field converge around a commons logic, we need to consider the dominant logics of each of the field's social actors. Because actors' interests do not develop in a sociocultural vacuum (Wejnert 2002), their individual frames (Benford and Snow 2000, Gray 2003) about field-level issues and their preferred actions for a field must be understood in terms of the dominant logics in the wider societal contexts in which they operate (Djelic and Quack 2008) and attempt to realize their interests. However, because transnational actors at multiple levels are subject to different institutional pressures, their logics and frames are likely to diverge substantially as they draw on widely different "cultural narratives and repertoires at hand" (Emirbayer and Mische 1998, p. 993) to develop their interpretations, theorizations, and representations of whether they share a common fate, whether their behavior contributes to the problem, and how the field ought to be governed. Therefore, actors in transnational fields may be guided by (variants of) different logics, drawn from the societal level (Friedland and Alford 1991), the field level (Thornton and Ocasio 1999), and/or the organizational level (Battilana and Dorado 2010), depending on the contexts in which they are embedded. Consequently, no institutional order with its accompanying logics is "accorded causal primacy a priori" (Thornton and Ocasio 2008, p. 104) in a transnational field.

To theorize about commons construction, it is necessary to understand the different and often conflicting logics that actors employ to ensure "order and ontological 
security" as well as how logics induce actors to frame problems differently and to advocate particular actions over others (Thornton and Ocasio 2008, p. 108; Purdy and Gray 2009). Identifying the diverse logics within a field lays the basis for a richer and more dynamic understanding of the differential capacity that actors have to mediate the structuring of contexts within which action unfolds. For new institutional arrangements to emerge, actors guided by different logics need to "build upon, work around, recombine, reinvent and reinterpret logics and institutional arrangements" (Djelic and Quack 2008, p. 308).

Frames and Frame Shifts. Whereas different (conflicting) logics in a field can coexist (Purdy and Gray 2009, Reay and Hinings 2009, Seo and Creed 2002), they may also blend (Glynn and Lounsbury 2005, Rao and Giorgi 2006), hybridize (Haveman and Rao 1997, Mars and Lounsbury 2009), or recombine (Djelic and Quack 2008). Such changes do not result from "accidental encounters" of diverse logics; instead, they usually involve deliberate attempts to persuade other actors to change their frames. By rendering events or occurrences meaningful, "frames function to organize experience and guide action, whether individual or collective" (Snow et al. 1986, p. 464). Because logics are manifested both in substantive behavioral actions and in actors' use of frames, reframing occurs through theorization of abstract models and representations as well as concrete behavioral manifestations and actions (Benford and Snow 2000, Nigam and Ocasio 2010).

Framing can also function as a rhetorical device through which actors create specific meaning in line with political interests (Fiss and Hirsch 2005, Suddaby and Greenwood 2005). For example, social movement theorists have argued how leaders attract adherents through frames that diagnose problems and assign blame, prognostic frames that lay out remedial actions, and motivational frames that provide rationales for action (Benford and Snow 2000). In contested institutional fields, frame analysis is a particularly useful tool for analyzing how field-level actors engage in discursive struggles to advance their respective logics and practices (Creed et al. 2002, Kaplan 2008, Elliott et al. 2003, Rydin 2003). Engagement among actors within a transnational field affords them opportunities for cognitive realignment and transformation of frames grounded in exemplars of those practices, as Nigam and Ocasio (2010) showed in the context of US healthcare.

Transnational fields are likely to be characterized by a "polysemy of frame repertoires" (Kaplan 2008, p. 746). As these fields evolve, the potential exists for field-level frames to emerge and diffuse if actors with divergent frames can reconcile their frame differences. Field frames emerge when the divergent frames of actors in a field converge around a shared frame
(Kaplan 2008, Lounsbury et al. 2003). Little attention has been given to what process mechanisms underlie shifts in actors' frames to enable consensus around field frames. Although the identification of mechanisms that enable field-level change has been argued to be critical for advancing theorization about institutions (Davis and Marquis 2005, Dobbin et al. 2007, Schneiberg and Clemens 2006), there is little consensus among scholars about what exactly constitutes a social mechanism and hardly any theorization about what mechanisms might enable actors to shift their frames on a transnational issue.

Multilevel Field Dynamics. To understand field changes, it is important to analyze the ways in which frames shift and disseminate in a field, and, consequently, a new logic may emerge. However, how a new logic emerges in transnational fields is not well understood. At the field level, researchers studying social problems (e.g., Best 2001) have proposed diffusion models drawing both on economic (e.g., Banerjee 1992) and sociological (e.g., Strang and Soule 1998) arguments to explain how social problems and claims are constructed and how they are adapted as they diffuse across time and space (Ansari et al. 2010). At the transnational level, Djelic and Quack (2008) suggested that more emergent modes of diffusion may operate with less predictable results. Drawing on these and related arguments (Purdy and Gray 2009, Sewell 1996), we question whether extant diffusion models sufficiently capture the complex dynamics at work in transnational fields (Watts 2003), where shifts in frames by actors at one level have wider, field-level repercussions (Tarrow 2005).

To sum, although institutional theory offers useful constructs for exploring transnational commons, (i.e., social construction, conflicting logics, and different level frame shifts), further research is needed to identify what constitutes a commons logic and what mechanisms induce actors with conflicting logics to change frames enough to reach a working consensus and promote the construction of a commons logic in a transnational field. We explore those questions in the field of climate change.

\section{Methodology}

Our data collection and analytic approach exemplifies what has been termed "historical process research" (Langley 1999, Pentland 1999, Van de Ven and Poole 2002). Process research does not focus on variance, but rather emphasizes the understanding of how and why "discrete events and states" (Elsbach and Sutton 1992, p. 708) evolve over time. Data for process research consist of events, activities, and choices ordered over time (Langley 1999). Studying processes can result in an articulation of routines and practices that remain relatively constant over time or of diachronic changes 
that emerge chronologically across time (Barley 1990). To show how the field of climate change came to be widely considered a commons, we needed a diachronic approach to track the evolution of the field over time and the development of consensus around a commons logic.

\section{Setting and Data Collection}

Given the scope of our topic and the volume of potential data we could gather, we needed to bound significantly. By perusing historical overviews of actors and events prior to the Kyoto Protocol (e.g., Grubb et al. 1999) and holding discussions with an expert who had been involved in climate policy negotiations during this period, we identified key actors in the field of climate change: science (Intergovernmental Panel on Climate Change (IPCC)), government (the European Union (EU), the US, and the Group of 77 (G-77), representing developing countries), business (corporations and trade associations), and civil society (transnational NGOs). In 2003, 24 interviews were held with 21 representatives of these actors ( 4 from science, 12 from government, 3 from business, and 2 from civil society), as well as 8 external experts (social scientists) who had observed the evolution of the climate field over time. These interviews lasted 30 to 90 minutes, with an average of 60 minutes, and produced 206 pages of transcripts. Interviewees were asked to chart the positions of key actors in the emerging field of global climate change, the rationales accounting for these positions, and how and why key actors had changed their viewpoints.

In parallel, we collected secondary data to trace new developments. We used key terms (such as climate change, climate policy, and global warming) to gather 290 articles in which climate change was the main topic from leading newspapers, mass media publications, and the Web for the period 2003-2010. These publications dealt with (changes in) the positions of key actors, the unfolding of climate negotiations, the status of climate agreements, and the science of climate change. We also perused a rapidly expanding (academic) literature on climate change. One author attended the Copenhagen Climate Summit (COP-15) in 2009 and collected 70 documents and digital repositories. Finally, we conducted seven targeted conversations in 2010-2011 with key informants to refine our understanding of actors' frame shifts. Overall, we created a fairly comprehensive set of data from which to identify and triangulate our findings about the key actors' logics and frames and the points at which, and reasons why, these frames shifted.

\section{Analytic Strategy}

The first step in our historical research process approach was the chronological identification of major historical events that marked the evolution of the debate in the field. We began with scientific attention to climate change as an issue of global concern in 1969 and ended with the Cancún Agreement in 2010. This produced a total of 13 historical events.

After demarcating the array of key historical events, in our second step, we began to examine which of these were field-configuring events-that is, those events that provided impetus for change within the institutional field (Hardy and Maguire 2010). According to Sewell (1996, p. 844), such an event is "(1) a ramified sequence of occurrences that (2) is recognized as notable by contemporaries, and that (3) results in a durable transformation of structures." To do this, we initially charted the frames and underlying logics of key actors during the focal period, and we assessed the extent to which these actors shifted their frames before, during, or after the historical events we had identified. We drew on the framework of Thornton et al. (2012) to classify actors' core logics. Four of them were evident in our data: the state logic (embraced by several national governments and NGOs), the professional logic (associated with science), the market logic (upheld by businesses and certain national governments), and the community logic (embraced by NGOs and some national governments). ${ }^{1}$ To identify the episodes when actors shifted their frames, we looked for what have been referred to as "discursive shifts" (Maguire and Hardy 2009) or " 'breaches' that reveal the usually undiscussed boundaries of taken-for-granted understandings" (Schneiberg and Clemens 2006, p. 214). This step resulted in the identification of 12 actor-level frame shifts.

Our third step was to search for underlying factors that induced actors to change frames in each of the 12 frame shifts identified above. We looked for evidence indicating if, how, and why different actors' frames and actions were either driving or driven by field-configuring events or by other actors' responses to these events. This required analyzing how frames and actions at one level affected those at other levels. We coded each frame shift for features that exemplified extant mechanisms in the literature, new ones, or variants of existing ones. This iterative process generated nine provisional mechanisms. By comparing the mechanism(s) for each frame shift, we realized commonalities among some of the mechanisms and collapsed the nine into five, more generic, mechanisms that prompted frame changes. Each category contained factors that were similar to other factors in that category yet distinct from those in other categories, thereby ensuring that each category showed both convergent and discriminant validity (Drucker-Godard et al. 1999). The resultant "mechanisms" (Davis and Marquis 2005) or "process drivers" (Langley 1999, p. 904) reside at a level of analysis above description and below universal laws, and they serve as theoretical explanations for change in institutional fields (Dobbin et al. 2007). The mechanisms reflect the exercise of individual agency in generating frame shifts as well as culturally mediated responses provoked by certain situations 
or in response to the actions of other stakeholders (Gross 2009). We created a label for each mechanism that captured the essence of the underlying explanation.

Our fourth step was to look more globally at the emergence of field frames (Lounsbury et al. 2003) arising from changes in actors' frames over time. Because we were interested in whether a commons was being constructed at the field level, we looked for evidence of how an initial frame advanced by one actor was reinforced when other actors also adopted it - that is, to what extent and at what point in time actors' frames about climate change began to converge at the field level. For this, we used a "temporal bracketing" approach (Langley 1999) to impose rough historical frameworks on the data. As Langley (1999) noted, the phases that result from temporal bracketing do not represent a predictable sequential process. Instead, these event data show nonrecurrent types of change (Abbott 1990) - in our case, whether and to what extent consensus was emerging over time. Because events and the altering of institutional arrangements are recursively related (Hoffman and Ocasio 2001), we demarcated the end of a phase with the occurrence of a discontinuity with the past. Temporal bracketing enabled us to demarcate generic differences in the nature of the climate debate for each bracketed period (as certain frames gained saliency, others receded in interest, and still others appeared for the first time) and to relate actor-level frame shifts to field-level changes.

Our fifth step was to array these field frame shifts in temporal order and examine their interrelations. From this analysis, three conditions emerged that capture the bases of an emerging consensus among actors about the climate change field as a commons: the view that their fates were interconnected, the acceptance of responsibility by all, and the need to take collective action. For each of these conditions, a cluster of actors (although not necessarily all) displayed similar framing.

Finally, we considered whether the mechanisms we identified in the third step could be linked to the three conditions necessary for a commons logic to emerge.
This resulted in a process model that explains how consensus develops around a transnational commons logic. For ease of presentation, we organize our findings around each phase.

\section{Findings}

Our empirical findings are structured by phase. The first period starts with early attention to climate change by the scientific community and ends in 1991, just before the Earth Summit in Rio de Janeiro. The second time phase begins with the 1992 Rio Conference and ends with the passage of the Kyoto Protocol in 1997. The final phase follows events from 1998 to 2010, when the Cancún Agreement was adopted. Figure 1 presents a chronology of major historical events across all three phases. For each phase, we organize our findings around the main events and key field frame(s) that emerged in that phase and the underlying actor-level shifts that gave rise to them (first-order analysis). We then introduce a model of the mechanisms associated with these shifts and show how they support the development of a commons logic over time in the field of climate change (our second-order analysis).

\section{Historical Background of the Climate Change Field}

Phase I: The Early Phase (1969-1991). Over the past century, climate scientists have noted that the average temperature of the Earth has risen significantly (Intergovernmental Panel on Climate Change 2007). This change, attributed to an increased release of largely imperceptible "greenhouse gases," is argued to have farreaching consequences, ranging from the melting of ice caps and the increased occurrence of flooding for some locales, to desertification for others, and to the loss of biodiversity worldwide. Although the idea that humans can change the climate dates back to 1827 (Grubb et al. 1999), nations began to worry about climate change only from the 1950s onward, and then only as a national security issue (e.g., desertification would cause widespread migration) that would require militaristic interventions to

Figure 1 Historical Events in the Field of Climate Change

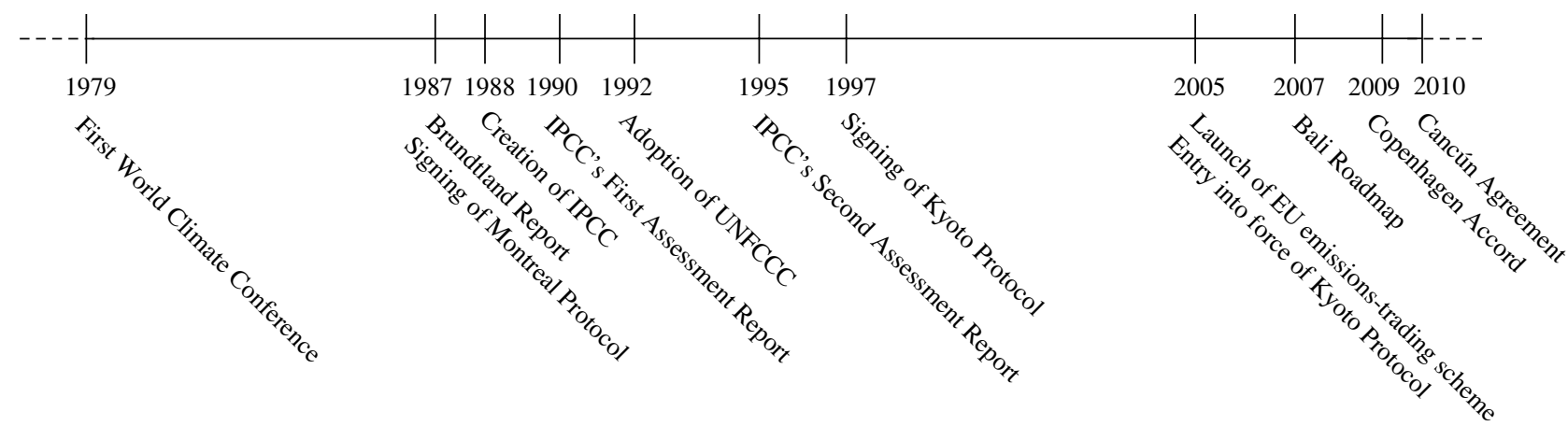


ensure peace (Finger 2008, Pettenger 2007). In the US, fallout from atmospheric nuclear testing in the 1950s also elevated the legitimacy of the idea that humans had to the potential to "trample" on Mother Earth and change the climate (Hart and Victor 1993). By the late 1960s, when our analysis begins, climate change research from several disparate streams (Hart and Victor 1993) was organized into a more coordinated, policy-oriented body of work (Demeritt 2001), and the issue moved from the restricted purview of a select group of scientists to make its debut on the transnational policy stage.

Field Frame 1: Viewing climate change as an anthropogenic, transnational problem. The first emergent field frame we identified was the growing agreement that climate change was an anthropogenic problem occurring at the transnational level. Two actor-level frame shifts ( $1 \mathrm{a}$ and $1 \mathrm{~b}$ ), initiated by elite scientists, NGOs, the US national government, and supranational organizations, could be seen as contributing to the development of this field frame.

Frame Shift la: The atmosphere is recast from a dump to a fragile and vulnerable space. Growing consensus among elite scientists about the atmosphere's vulnerability reflects the first major actor-level frame shift our data revealed. Prior to 1970, the narrow focus of research on weather and the atmosphere (e.g., on atmospheric modeling, carbon cycles, oceanography, and rainmaking) was siloed in different institutions with different funding sources (Hart and Victor 1993). However, from 1969 onward, several developments highlighted the necessity of a broader view linking these research streams. First, key institutional entrepreneurs ${ }^{2}$ within science and policymaking (including Robert Wilson at the Massachusetts Institute of Technology (MIT) and leaders of the World Meteorological Organization (WMO) and the United Nations (UN) Environment Program) began to frame climate change as a scientific issue of global concern. ${ }^{3}$ European and North American NGOs also contributed toward initiating this frame through launching a worldwide environmental movement to limit damage from the "treadmill of production" (Schnaiberg 1980, quoted by Rudel et al. 2011, p. 11.2) that gave rise to environmentalism as an "institution" in its own right (Frank et al. 2000). International actors such as the UN and WMO reinforced this frame by convening conferences that stressed the potential effects of climate change on humanity (the UN Conference on the Human Environment (UNCHE) or the Stockholm Conference in 1972 and the First World Climate Conference in 1979, respectively). Several historical events played a role in this shift. Extreme weather-related anomalies in the early 1970s (e.g., drought in the Soviet Union and unseasonably cold winters in the US) boosted the urgency to attend to climate change and prompted another elite entrepreneur, US Secretary of State Henry
Kissinger, to champion an increase in funding for climate change research in 1974 (Hart and Victor 1993). Throughout the 1980s, rising carbon dioxide levels in the atmosphere because of increasing discharge of automobile and jet engine exhausts and burning rubbish heaps were increasingly touted as a threat to climate stability. Other events include the successful 1987 Montreal Protocol on the global phasing out of ozone-depleting gases (Barrett 2003) and the ascendancy of the notion of sustainable development (popularized through the 1987 Brundtland Report) to simultaneously achieve economic development, environmental health, and social justice. Leveraging all these events (cf. Munir 2005), atmospheric scientists began to reconstruct the greenhouse effect as a clear threat and to define anthropogenic climate change as a transnational environmental issue that needed human intervention. Thus, between 1979 and 1991, the idea that science, operating under a professional logic, is the only "authority" that stands above and outside the fray as a uniquely privileged vehicle to what is true, objective, and hence undeniable (Demeritt 2001) gained ground and led the way for the emergence of scientific consensus on climate change (Uri and Bearman 2010).

Frame Shift 1b: Climate change goes from being a national issue to a transnational issue. In 1988, the perceived need among elite scientists and nation-states to establish an objective basis for climate policy materialized in the formation of the IPCC (a joint effort of the WMO and the UN). Although some skepticism among scientists remained at this time (McCright and Dunlap 2000), the IPCC, in its 1990 First Assessment Report, furthered the appreciation that humans were interconnected by invisible, potentially human-induced changes in the atmosphere's composition, thereby advancing the notion that the atmosphere is a transnational commons that needs to be governed. The UNCHE Conference, among others, established the basis for "soft law" or nonbinding agreements (Sands and Peel 2005), asserting that nation-states bear responsibility for transnational environmental protection-thereby limiting their sovereign rights when it came to environmental degradation. Amid increasing influence of transnational organizations, such as the International Monetary Fund and World Bank, some countries began to realize that strategies beyond a focus on national territorial defense and conquest were needed to address an issue in which their fates were interconnected. Climate change became not just an anthropogenic but also a transnational problem.

Phase II: The Pre-Kyoto Phase (1992-1997). Spurred by the IPCC's initial report as well as general concerns about the environment, political leaders of 188 countries worked to construct the UN Framework Convention on Climate Change (UNFCCC), signed at the 1992 Earth Summit in Rio de Janeiro. Key elements included the precautionary principle (i.e., action should be taken despite scientific uncertainty), acknowledgment 
of "common but differentiated responsibilities" for industrialized and developing nation-states, a vague notion of "equity," and expectations about returning to 1990 greenhouse gas emission levels (Grubb et al. 1999). The UNFCCC represents the first transnational effort to regulate emissions and marks a shift from a previous view of unbridled economic growth to sustainable growth, resting on the assumptions that the atmosphere is fragile and has limited capacity to absorb greenhouse gases without significant temperature increases and environmental degradation (Oberthür and Ott 1999).

By 1992, an increasing number of actors with divergent perspectives had become involved in international deliberations about climate change. Although there was a strong level of agreement among governments about the need for ameliorative action to stabilize emissions, not all actors subscribed to the idea that their fates were interconnected or that their actions contributed to climate change.

Table 1 charts the key actors as well as their logics, frames, and allies in the early to mid-1990s, including whether and how these subsequently changed. Some actors - the 15 member states of the EU, the Alliance of Small Island States (AOSIS; most threatened by climate change), and NGOs-embraced an environmentally oriented community logic, arguing that we share one planet with constrained resources, and a state logic, advocating for a regulatory frame with top-down policies and measures. However, another group of developed countries_-including Japan, the US,
Switzerland, Canada, Australia, Norway, and New Zealand-(eventually) joined forces in the JUSSCANNZ group to strongly oppose mandatory commitments and embrace what they viewed as cost-effective, voluntary, market-based initiatives. Next to these two camps was the G-77, a very diverse group of over 100 developing countries that were united by their determination that only industrialized countries, historically accountable for the lion's share of global emissions, should take action. The G-77 embraced aspects of a community logic that stresses reciprocity, as was evident in their argument that they were entitled to their "fair share" of the world's natural resources. Advancing an equity frame, they claimed that only historical polluters should be subject to mandatory regulations. However, the oil and gas producing countries of the G-77-backed by the Global Climate Coalition (GCC), a group of oil and gas producing companies-feared that restrictive measures would jeopardize their future income. Embracing a market logic and framing climate change as a hoax, they fiercely opposed such restrictive regulations. Although the different key actors had diverse logics and frames, they realized that coalitions with other major players were important to achieve a critical mass and bend any transnational agreement in their favor. Thus, the EU heavily relied on the IPCC's findings and largely sided with the non-Organization of the Petroleum Exporting Countries (OPEC) G-77 members and environmental NGOs. The JUSSCANNZ group joined forces with OPEC countries and the GCC.

Table 1 Key Actor Logics, Frames, and Allies

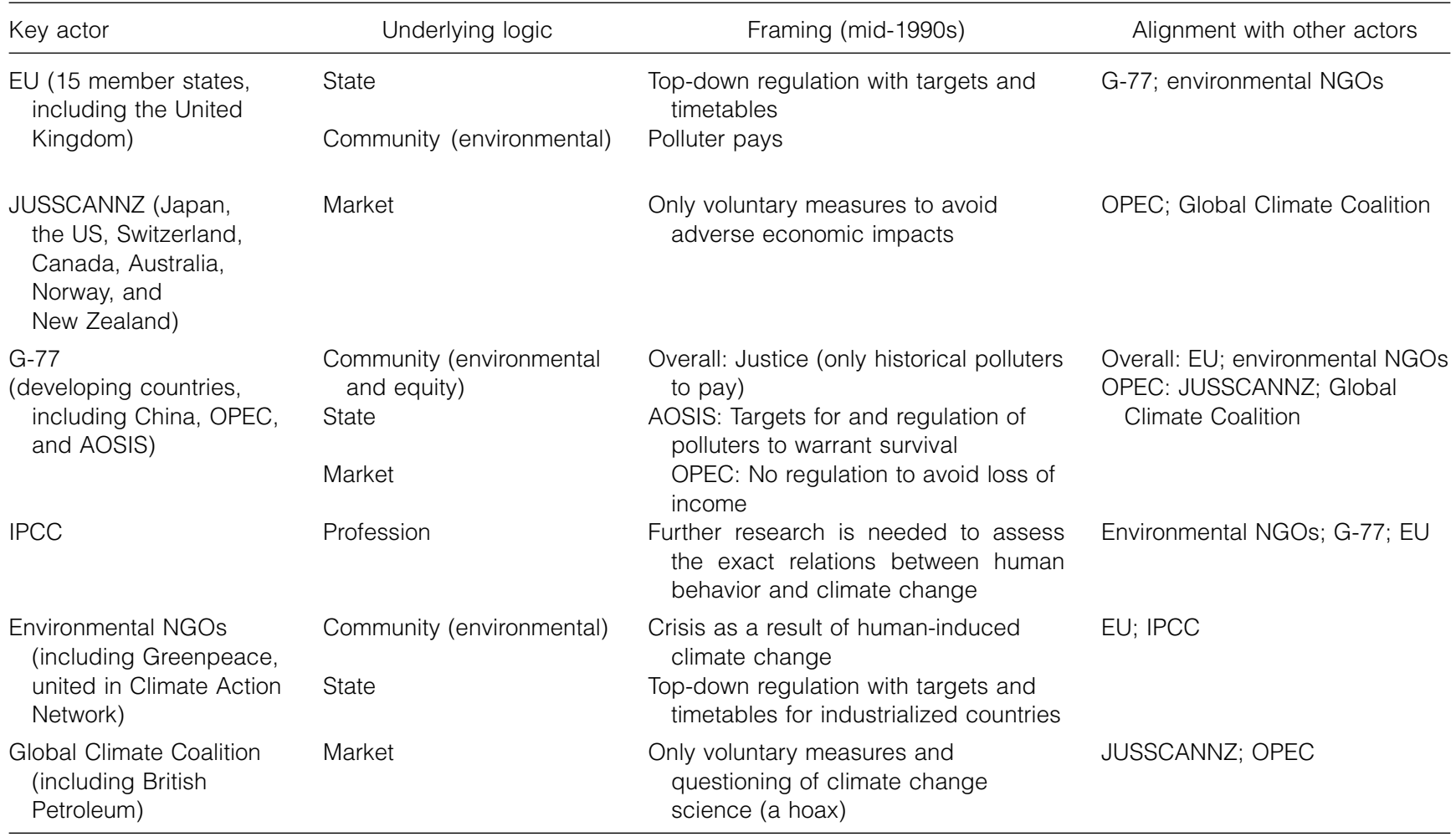


Field Frame 2: Accepting binding targets for historical polluters. As we noted above, not all actors saw the need to limit emissions or otherwise address climate change. However, in the run-up to the Kyoto Protocol, key players began to agree that emission caps for historical polluters were needed. The IPCC's $(1995$, p. 10) Second Assessment Report, which stated that "the balance of evidence suggests a discernible human influence on global climate," served as a trigger for two reinforcing actor-level frame shifts that contributed to the emergence of the field frame on emissions caps. Also in 1995, dissatisfied with the elusive nature of the Rio commitments, national delegates to the first Conference of the Parties (COP) started negotiating a comprehensive global climate agreement, in which the AOSIS delegation pushed for binding emission targets for industrialized countries.

Frame Shift 2a: The US evolves from pursuing voluntary measures to binding emission-reduction targets. Initially, the US strongly preferred pursuing voluntary emission-reduction measures only. It opposed any binding regulations that would curtail civic freedom or harm business or the US economy. Against the backdrop of the AOSIS proposal and the IPCC report, in 1996, the US formally proposed quantified national emission targets while holding on to the inclusion of market mechanisms (Grubb et al. 1999). The US concession was imperative to the conclusion of the Kyoto Protocol.

Frame Shift 2b: The EU moves from top-down regulation only to regulation and binding targets. When binding emission targets were formally on the table, the EU readily embraced them as a way to seriously commit industrialized countries to mitigation efforts. While accepting the principle of binding targets, the EU also kept insisting on top-down government regulation in the run-up to Kyoto (Grubb et al. 1999). The EU's endorsement of binding targets reinforced the support of the field frame that countries with historical responsibility for climate change were bound by emission caps.

Field Frame 3: Viewing global carbon markets as acceptable mitigation instruments. The third unfolding field frame involved overcoming resistance to the principle of using market instruments for climate change mitigation. These three key interpretive shifts, all related to the Kyoto negotiations, occurred and contributed to the growing acceptance of market principles to mitigate climate change. After protracted negotiations, both the polluter-pays frame and the ecological modernization frame, which advocates "compatibility between economic growth and environmental protection" (Bäckstrand and Lövbrand 2007, p. 129), became cornerstones of the ensuing Kyoto Protocol, signed at COP-3 in 1997 and ratified in 2005 by 188 countries, including China but excluding the US (UN Framework Convention on Climate Change 2009). The protocol, requiring an average $5.2 \%$ reduction in greenhouse gas emissions by developed countries below 1990 levels by 2008-2012, allows for the introduction of flexible mechanisms favored by several developed countries and exempts the G-77 nations from emission reduction targets (Grubb et al. 1999). The flexible mechanisms included emissions trading, joint implementation (JI; involving foreign projects among industrialized countries), and the clean development mechanism (CDM; a project-based financing mechanism in which industrialized countries could comply with their emission reduction commitments in developing countries).

Frame Shifts $3 a, 3 b$, and $3 c:$ G-77, EU, and Greenpeace go from being regulation advocates to market endorsers. An important shift was the unexpected change in framing of the G-77, which led to its members' acquiescence to the Kyoto Protocol. The G-77 was designed to promote the collective economic interests of developing countries and to increase their joint negotiating capacity in the UN. Staunchly behind the polluter-pays frame, this coalition had opposed market mechanisms for being a strategic ploy and an instance of "carbon colonialism," where industrialized countries could use their land as "carbon dumps" to generate emission credits ("permits to pollute") and sidestep significant domestic action for emission reductions (Grubb et al. 1999). However, a breakthrough emerged during the pre-Kyoto negotiations, when Brazil proposed the creation of an adaptation fund for climate-vulnerable countries that would be financed by charging industrialized countries for noncompliance. Linking this proposal with the US demand for binding commitments from the G-77 led to the adoption of the CDM. Eventually, the G-77 also accepted two other flexible market mechanisms (JI and emissions trading) in return for the promise of green investments in their countries, enabling the Kyoto agreement to be forged in 1997-a reversal that later came to be known as the "Kyoto Surprise" (Grubb et al. 1999). Chairman Raúl Estrada-Oyuela also played an influential role in crafting the text to secure binding commitments, as he ignored several objections raised by India and China.

Like the developing countries, EU member states had favored mandatory action and advocated a strong regulative framework to harmonize and coordinate the (environmental) policies of different nation-states (Grubb et al. 1999). Eventually, however, the EU shifted this frame-abandoning their demand for prescriptive actions and accepting flexible market instruments instead, while still insisting on the principle of binding emission caps. The acceptance of market instruments by the G-77 and the EU cleared a major obstacle to the conclusion of the Kyoto Protocol.

Not only nation-states but also certain NGOs gave up their resistance to using markets for mitigation purposes. In the run-up to Kyoto, most environmental NGOs, including Greenpeace, were strong supporters of the polluter-pays frame, fearing that that the use of JI 
would exempt rich nations from taking responsibility for polluting. Greenpeace, for example, rejected US proposals for market solutions because they preferred regulations over flexible, market-based solutions to climate change. Additionally, market mechanisms were seen as another move by "the carbon club" to stall real action (Leggett 1999). Nonetheless, despite their push for regulations, the NGOs were unsuccessful, because all of the market mechanisms that the US proposed became cornerstones of the Kyoto Protocol. Once the G-77, originally a staunch opponent of these mechanisms, came on board, Greenpeace increasingly became aware of the handwriting on the wall and agreed to what had been a distant second choice for them-the idea of using markets. In one of our interviews, a Greenpeace representative noted, "The majority of environmental groups were opposed to flexible mechanisms. This is a battle we lost in Kyoto. People say that is part of the protocol, so now we cannot go against that... There is no point in continuing to oppose it, because it is there." Greenpeace's shift from top-down regulatory framing to prudent support for market-based instruments increased the number of stakeholders who supported market-based mitigation measures.

Phase III: The Post-Kyoto Phase (1998-2010). Just after the unanimous adoption of the Kyoto Protocol, nation-states waited for its entry into force. This required the adoption by $55 \%$ of signatory nations representing at least $55 \%$ of emissions by industrialized countries. However, when the US rejected the protocol in 2001, to meet this double-threshold hurdle, it was imperative that Russia ratify the protocol, which did not occur until 2004. Whereas many nation-states remained relatively passive during this uncertain period, several other actors changed their frames regarding the adoption of mitigation actions.

Field Frame 4: Implementing carbon market instruments for climate change mitigation. A major field frame that gained currency after the adoption of the Kyoto Protocol was the development and implementation of specific market instruments. Several key actors shifted their frames, thereby increasing support for the actual use of markets for mitigating climate change.

Frame Shifts 4a, 4b, and 4c: British Petroleum/ UK/EU move from avoiding/delaying/opposing marketbased mitigation action to adopting emissions trading. A set of changes occurred between 1997 and 2003 in a sort of amplifying or domino effect, beginning with decisions taken by British Petroleum (BP), then the United Kingdom (UK) government, and ultimately the EU. Until just before the adoption of the Kyoto Protocol, the GCC, representing oil and gas companies and other major emitters, had opposed emission reduction measures writ large. However, in a surprise move in May 1997, BP's CEO, John Browne, broke ranks with most other oil-and-gas companies. BP left the GCC and became the first MNC to commit to emission cuts and set up an internal carbon-trading market among its divisions (Levy and Kolk 2002). An observer we interviewed attributed this to "the personal influence of John Browne. It would have been simply irresponsible for him to look away and, therefore, he decided to break away from the pack" - a view Browne himself corroborated in our interview with him. BP's split from the rest of the oil-and-gas industry was widely interpreted as a statement of business support for a market approach to greenhouse gas mitigation (Pulver 2007) that could preempt restrictive regulation and as an initiative to strengthen renewable energy in its overall portfolio. The BP case has become one of the most widely cited best practices in corporate climate change initiatives, because BP managed to achieve its $10 \%$ reduction goal by 2001 and claimed to have generated 600 million US dollars in cost savings (Pinkse and Kolk 2009). Thus, BP framed its carbon-trading scheme as ecological modernization with both economic and reputational benefits (Margolick and Russell 2001). ${ }^{4}$

Concurrently, the UK engaged in developing nationallevel climate change policies. In 1989, the Thatcher government advocated a framework convention on climate change. It refused, though, to back specific carbonreduction commitments, invoking the need for greater scientific certainty. The UK's frame shift was induced by the convergence of several factors. Next to the country's rapid shift from coal to natural gas, the UK government was also not immune to the actions of some of its largest MNCs (e.g., BP) and sought their advice in developing the country's emissions-trading scheme, which began in 2002 (Kolk and Pinkse 2007). According to one interviewee, "BP was a major high-profile company and its actions couldn't have gone unnoticed at the highest level. The new Labour government, elected in 1997, wanted to show it was serious about climate change."

BP's actions, and subsequently those of the UK, to develop trading schemes were then pivotal in spurring the EU-opposed to emissions trading during the Kyoto negotiations (for fear that it would allow developed countries to weasel out of their emission reduction obligations) - to shift its framing of this issue in 2000. The EU abandoned its top-down regulatory frame and took preemptive action to thwart the development of a "patchwork of different national schemes" (Engels 2006, pp. 341-342) among its member states (such as the UK and Denmark) by introducing its own scheme in 2005 . With growing experience from various pilot projects, BP and later Shell became key advisors in the development of guidelines for the EU's scheme (Engels 2006). BP's frame shift stimulated progressive businesses to assume responsibility for the commons problem, and the adoption of market-based instruments by BP, the UK, and the EU constituted important support in the field for using market instruments to protect the climate commons. 
Field Frame 5: Taking mitigation actions without formal obligations. The final emerging field frame concerns the voluntary commitment to mitigation measures by actors without formal obligations to do so. This frame received a significant boost in the field when subnational actors within the US, a lagging nation-state that had not ratified the Kyoto Protocol, and major developing countries, who had signed but were exempt from mitigation obligations, agreed to take ameliorative actions for mitigating climate change.

Frame Shift 5a: US subnational actors evolve from supporting inaction to ecological modernization. Despite its early support for the Kyoto agreement, the US conspicuously lagged behind the EU in committing to emission reductions (Vogel et al. 2012) and ultimately refused to ratify the treaty. Given the lowprice energy culture in the US, many US legislators had viewed mitigation measures as an economic burden (Grubb et al. 1999). In particular, the Republican Party publicly expressed skepticism about some of the claims regarding climate change. However, early in the new millennium, a remarkable bottom-up shift began to occur in the US, led by several states that broke ranks with the federal government on the climate change issue. Foot-dragging by the Bush administration and opposition to binding mitigation measures by the US Congress was in stark contrast to the behaviors of many US states, cities, corporations, universities, and churches. Inspired by actions in the EU and mass mediatization such as Al Gore's documentary An Inconvenient Truth, they voluntarily took on relatively ambitious emission-reduction targets (Vogel et al. 2012). By 2003, the US Environmental Protection Agency (2003) had catalogued over 700 state policies to reduce greenhouse gas emissions. By 2006, 28 states had produced climate action plans (Pew Center on Global Climate 2010). In 2007, joint commitment evolved into a 10-state, mandatory cap-andtrade program called the Regional Greenhouse Gas Initiative. Several US cities also endorsed climate change programs in 2005, led by the US Mayors Climate Protection Program and signed by 200 mayors from 38 states. Several prominent US universities led the Campuses for Climate Action project, whereas a number of religious associations (such as the National Council of Churches) actively campaigned for mitigation measures. Furthermore, chief executives of some of the largest US companies, including General Electric and Walmart, formed the US Climate Action Partnership in 2005 and launched high-visibility green branding campaigns, supporting an emission cut of over $60 \%$ by 2050 . By advocating and taking concrete actions for ecological modernization, these US subnational actors contributed to a discernible bottom-up shift on climate change in the US.

Frame Shift 5b: BASIC countries go from being exemption seekers to responsibility accepters. In the decade following the Kyoto Protocol, several high-growth G-77 countries (especially Brazil, South Africa, India, and China-the so-called "BASIC" group) rapidly increased their share in the global emissions of greenhouse gases. For example, China outpaced the US in 2006 as the largest emitter of carbon dioxide (New York Times 2007). Faced with difficulties in securing the energy to fuel their economic expansion, these emerging countries increasingly realized that, although exempted from mandatory action, it was in their own interest to adopt more proactive climate policies (Heggelund and Buan 2009). Consequently, to preempt their marginalization in future transnational policymaking, these large G-77 economies shifted their frames from "polluter pays" to "ecological modernization." This brought the US back to the negotiation table and culminated in the 2007 Bali Roadmap (Ott et al. 2008), whose realization was fostered by the UNFCCC executive secretary. Subsequently, although the highly awaited 2009 Copenhagen Climate Summit (COP-15) did not generate an agreement with binding commitments, it did produce an important shift in the BASIC countries' receptivity toward (relative) emission reduction targets for their countries, which was formally confirmed at the 2010 Cancún Agreement (COP-16). Their pledge to assume responsibility and take action was a significant step toward increasing consensus around a transnational commons logic. Table 2 summarizes major field frames and related actor-level frame shifts, and it shows mechanisms and consequences that we explain next.

\section{The Social Construction of a Commons Logic About Climate Change}

In addition to tracking the 12 actor-level frame shifts, close examination of the unfolding field frames enabled us to see whether and how these shifts contributed to an emerging consensus about climate change among key players in the field between 1969 and 2010. Our analysis revealed that, eventually, a number of actors converged around a commons logic for climate change, although not all the key actors embraced this logic simultaneously and to the same extent. We found that the emerging logic of climate change as a transnational commons involves the satisfaction of three conditions. First, actors must agree that a problem exists in which their fates are interconnected. Thus, no actor can escape the consequences of the problem. Second, a commons logic requires actors to perceive the vulnerability of the resource as a critical issue and to implicate themselves as part of the problem. Third, actors must commit themselves to mitigation actions that address the problem and diminish the degradation of the commons. Satisfaction of this condition enables the development of governance mechanisms for a transnational commons. As the five field frames gained currency, increasing convergence around these three conditions gradually emerged. 
Table 2 Field Frames, Actor-Level Frames, Actions, and Mechanisms

\begin{tabular}{|c|c|c|c|c|c|c|}
\hline Year(s) & Actor shift no. & Initial frame & New frame & Action & Mechanism & Explanation \\
\hline \multicolumn{7}{|c|}{ Field Frame 1: Viewing climate change as an anthropogenic, transnational problem } \\
\hline 1969-1991 & $1 a$ & $\begin{array}{l}\text { The atmosphere is a } \\
\text { "dump" with unlimited } \\
\text { capacity or a national } \\
\text { security issue }\end{array}$ & $\begin{array}{l}\text { The atmosphere is a } \\
\text { fragile global } \\
\text { commons, } \\
\text { vulnerable to } \\
\text { human-induced } \\
\text { degradation }\end{array}$ & $\begin{array}{l}\text { UNCHE and WMO } \\
\text { conferences voice } \\
\text { concerns about } \\
\text { human damage to } \\
\text { environment }\end{array}$ & $\begin{array}{l}\text { Collective } \\
\text { theorizing }\end{array}$ & $\begin{array}{l}\text { Gradual acceptance } \\
\text { of human impact on } \\
\text { climate change }\end{array}$ \\
\hline \multirow[t]{2}{*}{1988} & $1 b$ & $\begin{array}{l}\text { Climate-induced problems } \\
\text { are national issues that } \\
\text { create territorial } \\
\text { disputes }\end{array}$ & $\begin{array}{l}\text { Human-induced } \\
\text { changes in the } \\
\text { atmosphere pose a } \\
\text { transnational } \\
\text { commons problem }\end{array}$ & $\begin{array}{l}\text { Scientists report } \\
\text { evidence of } \\
\text { climate change }\end{array}$ & $\begin{array}{l}\text { Collective } \\
\text { theorizing }\end{array}$ & $\begin{array}{l}\text { Environmentalism } \\
\text { emerges as an } \\
\text { "institution" }\end{array}$ \\
\hline & & \multicolumn{5}{|c|}{ Field Frame 2: Accepting binding targets for historical polluters } \\
\hline $1996-1997$ & $2 a$ & $\begin{array}{l}\text { Climate policy is a an } \\
\text { economic threat; only } \\
\text { voluntary targets are } \\
\text { reasonable }\end{array}$ & $\begin{array}{l}\text { Binding targets are } \\
\text { permissible when } \\
\text { accompanied by } \\
\text { flexible market } \\
\text { instruments }\end{array}$ & $\begin{array}{l}\text { The US formally } \\
\text { proposes binding, } \\
\text { quantified targets } \\
\text { in conjunction with } \\
\text { flexible market } \\
\text { instruments }\end{array}$ & $\begin{array}{l}\text { Issue } \\
\text { linkage }\end{array}$ & $\begin{array}{l}\text { The US combines the } \\
\text { AOSIS proposal of } \\
\text { binding targets with } \\
\text { its own preference } \\
\text { of cost-effective } \\
\text { market instruments }\end{array}$ \\
\hline $1996-1997$ & $2 b$ & $\begin{array}{l}\text { Top-down regulation is } \\
\text { imperative to mitigate } \\
\text { climate change }\end{array}$ & $\begin{array}{l}\text { Top-down regulation } \\
\text { and binding targets } \\
\text { are imperative to } \\
\text { mitigate climate } \\
\text { change }\end{array}$ & $\begin{array}{l}\text { The EU becomes a } \\
\text { strong advocate of } \\
\text { binding national } \\
\text { targets }\end{array}$ & $\begin{array}{l}\text { Active } \\
\text { learning }\end{array}$ & $\begin{array}{l}\text { The EU readily } \\
\text { subscribes to the } \\
\text { US proposal of } \\
\text { binding targets to } \\
\text { obtain strong } \\
\text { commitment by } \\
\text { industrialized } \\
\text { nations }\end{array}$ \\
\hline \multicolumn{7}{|c|}{ Field Frame 3: Viewing global carbon markets as acceptable mitigation instruments } \\
\hline 1997 & $3 a$ & $\begin{array}{l}\text { Domestic policies and } \\
\text { measures are } \\
\text { imperative for historical } \\
\text { polluters }\end{array}$ & $\begin{array}{l}\text { Global market } \\
\text { instruments for } \\
\text { historical polluters } \\
\text { are acceptable }\end{array}$ & $\begin{array}{l}\text { G-77 } \\
\text { proposes a } \\
\text { compensation fund } \\
\text { for developing } \\
\text { countries and } \\
\text { gives up } \\
\text { resistance to } \\
\text { market instruments }\end{array}$ & $\begin{array}{l}\text { Issue } \\
\text { linkage }\end{array}$ & $\begin{array}{l}\text { Prospects of "free" } \\
\text { investments pave } \\
\text { the way for G-77 } \\
\text { accepting market } \\
\text { instruments }\end{array}$ \\
\hline 1997 & $3 b$ & $\begin{array}{l}\text { Prescriptive policies and } \\
\text { measures are required } \\
\text { for industrialized } \\
\text { countries }\end{array}$ & $\begin{array}{l}\text { Global market } \\
\text { instruments are } \\
\text { acceptable when } \\
\text { including binding } \\
\text { emission targets }\end{array}$ & $\begin{array}{l}\text { The EU gives up } \\
\text { resistance to } \\
\text { market instruments }\end{array}$ & $\begin{array}{l}\text { Issue } \\
\text { linkage }\end{array}$ & $\begin{array}{l}\text { The EU gets its } \\
\text { much-desired } \\
\text { climate agreement } \\
\text { with binding } \\
\text { individual emission } \\
\text { caps }\end{array}$ \\
\hline$\sim 2000$ & $3 c$ & $\begin{array}{l}\text { Prescriptive policies and } \\
\text { measures are } \\
\text { imperative for polluters }\end{array}$ & $\begin{array}{l}\text { Market-based } \\
\text { instruments are } \\
\text { acceptable }\end{array}$ & $\begin{array}{l}\text { Greenpeace shifts } \\
\text { from advocating } \\
\text { prescriptive } \\
\text { regulation to } \\
\text { acquiescing to } \\
\text { market-like } \\
\text { measures }\end{array}$ & $\begin{array}{l}\text { Legitimacy } \\
\text { seeking }\end{array}$ & $\begin{array}{l}\text { Having lost former } \\
\text { allies, Greenpeace } \\
\text { has to reconsider its } \\
\text { position to regain } \\
\text { influence }\end{array}$ \\
\hline
\end{tabular}

In Phase 1 (between 1969 and 1991), leading scientists, environmental NGOs, and the US government came to concur about the first condition while many others still did not subscribe to it. In Phase 2 (1992-1997), some of the original actors also subscribed to the second condition, whereas additional actors signed on to the first condition. In Phase 3, still greater acceptance of the first two conditions occurred, although acceptance of Condition 3 was still not widespread, even by 2010 . Thus, the logic that climate change is a transnational commons has not yet been fully constructed within the field. Figure 2 represents the evolving consensus around each of the three conditions.

By arraying the frame changes and mechanisms chronologically, we also realized that certain mechanisms enabled stakeholders to converge in their framing 
Table 2 (cont'd)

\begin{tabular}{|c|c|c|c|c|c|c|}
\hline Year(s) & Actor shift no. & Initial frame & New frame & Action & Mechanism & Explanation \\
\hline & \multicolumn{6}{|c|}{ Field Frame 4: Implementing carbon market instruments for climate change mitigation } \\
\hline 1997-2003 & $4 a$ & $\begin{array}{l}\text { Climate change is } \\
\text { not man-made } \\
\text { and mitigation } \\
\text { measures are } \\
\text { costly }\end{array}$ & $\begin{array}{l}\text { Climate change is } \\
\text { human-induced } \\
\text { and responsibility } \\
\text { needs to be } \\
\text { assumed }\end{array}$ & $\begin{array}{l}\text { BP leaves Global } \\
\text { Climate Coalition } \\
\text { and creates an } \\
\text { intrafirm } \\
\text { carbon-trading } \\
\text { scheme }\end{array}$ & $\begin{array}{l}\text { Active learning } \\
\text { Legitimacy } \\
\text { seeking }\end{array}$ & $\begin{array}{l}\text { Moral legitimacy and } \\
\text { cost factors drive BP } \\
\text { to become first mover }\end{array}$ \\
\hline 2002 & $4 b$ & $\begin{array}{l}\text { Climate policy is } \\
\text { an economic } \\
\text { threat }\end{array}$ & $\begin{array}{l}\text { Ecological } \\
\text { modernization } \\
\text { reconciles } \\
\text { different interests }\end{array}$ & $\begin{array}{l}\text { The UK adopts } \\
\text { national policy } \\
\text { inspired by BP's } \\
\text { carbon-trading } \\
\text { scheme }\end{array}$ & $\begin{array}{l}\text { Catalytic } \\
\text { amplification }\end{array}$ & $\begin{array}{l}\text { BP and shell are } \\
\text { influential in UK } \\
\text { climate policy } \\
\text { preparation }\end{array}$ \\
\hline \multirow[t]{2}{*}{2005} & $4 \mathrm{C}$ & $\begin{array}{l}\text { Prescriptive } \\
\text { policies and } \\
\text { measures are } \\
\text { required }\end{array}$ & $\begin{array}{l}\text { Ecological } \\
\text { modernization is } \\
\text { efficient }\end{array}$ & $\begin{array}{l}\text { The EU harmonizes } \\
\text { emissions-trading } \\
\text { schemes of } \\
\text { individual member } \\
\text { states }\end{array}$ & $\begin{array}{l}\text { Active learning } \\
\text { Catalytic } \\
\text { amplification }\end{array}$ & $\begin{array}{l}\text { The UK scheme strongly } \\
\text { influences the EU's } \\
\text { choice of one single } \\
\text { scheme to guarantee } \\
\text { a single market }\end{array}$ \\
\hline & \multicolumn{6}{|c|}{ Field Frame 5: Taking mitigation actions without formal obligations } \\
\hline$\sim 2000$ & $5 a$ & $\begin{array}{l}\text { US participation is } \\
\text { contingent on } \\
\text { actions of all } \\
\text { other countries }\end{array}$ & $\begin{array}{l}\text { Ecological } \\
\text { modernization } \\
\text { reconciles } \\
\text { different interests }\end{array}$ & $\begin{array}{l}\text { Local governments } \\
\text { break with federal } \\
\text { stance and initiate } \\
\text { local actions to } \\
\text { reduce carbon } \\
\text { footprint }\end{array}$ & $\begin{array}{l}\text { Legitimacy } \\
\text { seeking } \\
\text { Catalytic } \\
\text { amplification }\end{array}$ & $\begin{array}{l}\text { Moral convictions } \\
\text { coupled with national } \\
\text { inaction and } \\
\text { transnational role } \\
\text { models spur local } \\
\text { actions }\end{array}$ \\
\hline 2009 & $5 b$ & $\begin{array}{l}\text { Mitigation actions } \\
\text { are only for } \\
\text { historical } \\
\text { polluters }\end{array}$ & $\begin{array}{l}\text { All major polluters } \\
\text { need to assume } \\
\text { responsibility and } \\
\text { act }\end{array}$ & $\begin{array}{l}\text { BASIC countries } \\
\text { pledge to realize } \\
\text { much higher } \\
\text { energy-efficiency } \\
\text { rates in their } \\
\text { economies }\end{array}$ & Active learning & $\begin{array}{l}\text { BASIC countries } \\
\text { become aware of the } \\
\text { necessity of proactive } \\
\text { climate measures to } \\
\text { sustain domestic } \\
\text { economic growth }\end{array}$ \\
\hline
\end{tabular}

Notes. In Field Frame 1, elite actors advance the view that climate change is a human-induced, global problem (Condition 1); the initiators are elite scientists, environmental NGOs, the US, and transnational organizations. In Field Frame 2, the EU and US accept binding targets, leading most industrialized countries to accept responsibility for their historically high emissions (Condition 2), and the initiator is AOSIS. In Field Frame 3, major countries, firms, and NGOs share the view that global market instruments can mitigate climate change (Condition 3), and the initiator is the US. In Field Frame 4, actors at multiple levels launch carbon trading schemes (Condition 3), and the initiator is BP. In Field Frame 5, actors not committed by the Kyoto Protocol recognize their responsibility (Condition 2) and commit to mitigation actions (Condition 3); initiators include the EU and the UNFCCC executive secretary.

over time, progressively satisfying each commons condition. We identified five distinct underlying mechanisms that facilitated the interpretive shifts within the field and the emergence of consensus about a commons logic. By linking our mechanisms with the conditions for the emergence of a commons logic, we developed a secondorder process model for this evolution (see Figure 3). We now describe how each condition emerged from our data and which mechanism(s) served to promote greater consensus around each one.

Condition 1. Prior to the introduction of ideas about climate change as a phenomenon of concern, the Earth's climate was viewed as a commodity for unfettered private use. With climate change, the Earth and its future became socially redefined as a shared concern in which the fates of its people became interconnected. This significant change in the depiction of the humanity-nature relationship marked a frame shift from a previous view of unbridled economic growth, based on a strong market logic, to one of ecological interdependence, rooted in the community logic, where one "shared planet" is seen to have a limited capacity to absorb the greenhouse gases without significant temperature increases and environmental degradation (Oberthür and Ott 1999). This awareness of interconnected fates forms the first condition for the construction of a commons logic: the problem is neither salient nor of concern to many actors without widespread consensus about this interdependence. For this first condition to be met, certain actors must theorize the existence of a problem that affects everyone, whereas others must subscribe to this thesis. As Figure 2 reveals, this began to happen for some actors in the early phase and was largely satisfied in 1992, when political leaders of 188 countries adopted the UNFCCC at the Rio Earth Summit. By 2010, the majority of key actors in the climate change field had accepted this condition. In particular, the emergence of environmentalism as a component of the community logic-with a cognitive shift from nature versus society (with efforts at subjugating 
Figure 2 Degree of Consensus Around Key Conditions of a Climate Change Logic

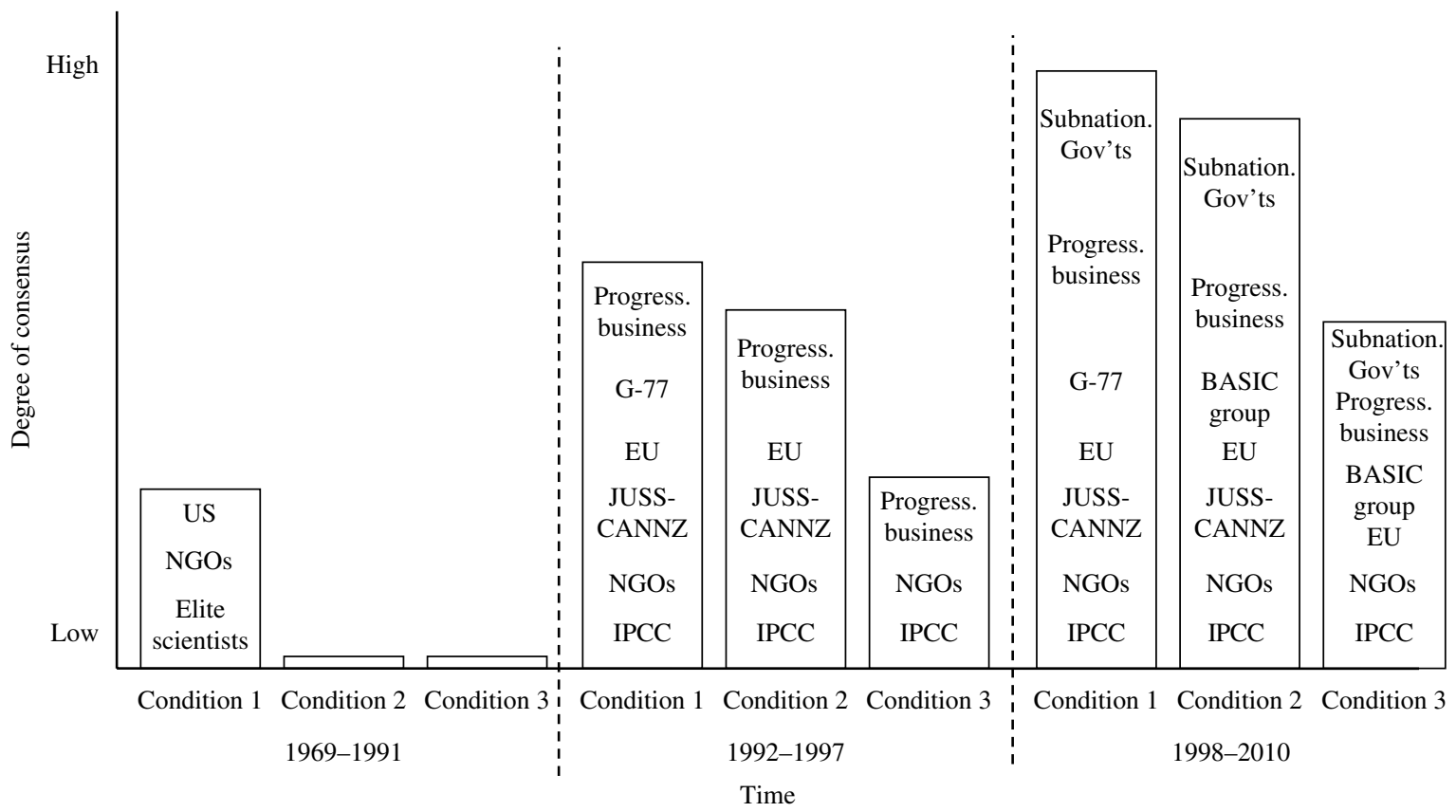

and eradicating nature) to nature for society (emphasizing interdependence between humans and ecosystems)played a major role in shifting some actors toward acceptance of this first condition (Frank et al. 2000).
This led human beings to be seen as increasingly responsible for sustaining the global ecosystem. We now examine the mechanism that promoted consensus around this first condition.

\section{Figure 3 Process Model for the Evolution of a Commons Logic}

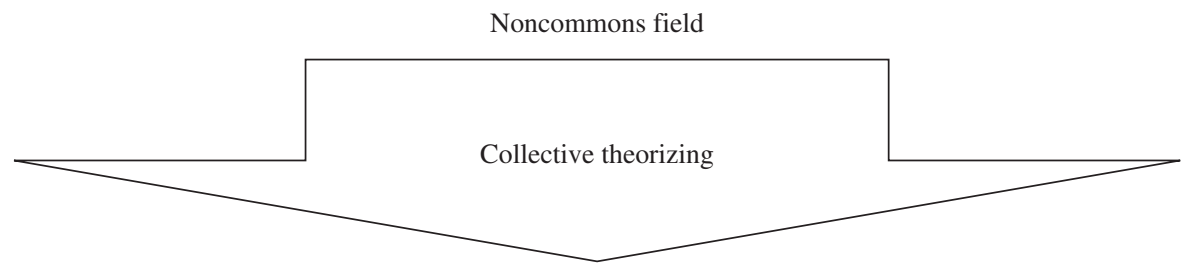

Condition 1: Recognition of interconnected fate

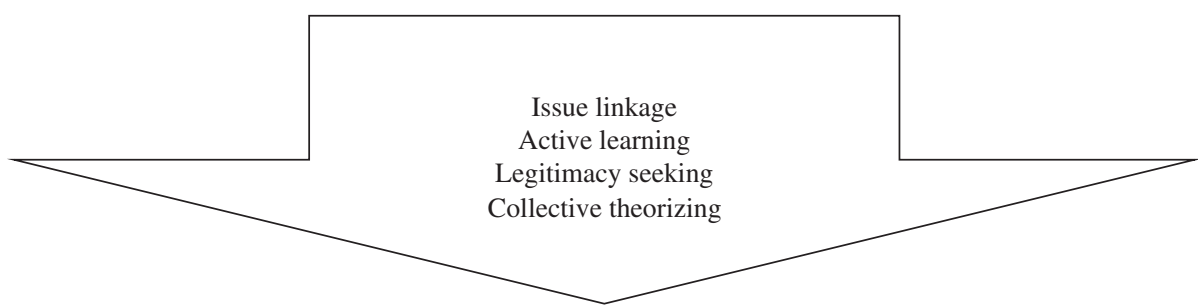

Condition 2: Acceptance of responsibility by all

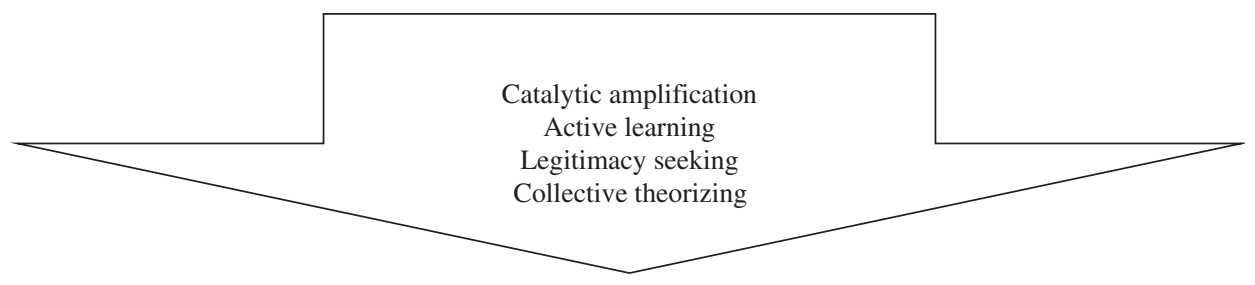

Condition 3: Collective commitment to act 
Satisfying the first condition for a transnational commons began with the increasingly shared view that a problem existed in which the fates of actors are interconnected (Trist 1983, Van Gusteren 1998). Our data suggest that collective theorizing (cf. Strang and Soule 1998) about "recursive" shocks is the mechanism that promoted this awareness. ${ }^{5}$ Several elite US politicians and scientists, who collectively served as institutional entrepreneurs, lobbied to support the research that eventually helped to define anthropogenic climate change as an environmental issue. Initially, scientists engaged in collective theorizing in response to extreme weather events that served as a key mechanism for change. Elite oceanographers and atmospheric scientists leveraged opportunities generated by various events to reconstruct anthropogenic climate change as a threat to a valued resource that needed protection from brazen industrialism. By defining climate change as an environmental issue, these scientists broadened the scope of environmentalism and, in the process, created "crisis awareness" about the issue, diffusing it to a higher level of public and political attention and attracting increased budgets by policy makers to address it. Thus, they rendered these events disruptive enough to bring them to wider notice. Elite entrepreneurship was evidenced in this early period by MIT's Wilson, the WMO, and the UN Environment Programme, who began to raise levels of public attention and political interest in the "crisis." Consequently, many actors began to embrace the first condition of a commons logic.

Condition 2. The second condition of a commons logic requires actors to construct resource vulnerability as a critical issue and to implicate themselves as part of the problem (e.g., overuse by all has led to degradation of the commons). Without a readily identifiable villain, everyone is required to take collective responsibility if the problem is going to be addressed. The acceptance of market instruments by the G-77 and the EU, as well as the US's and EU's consent to binding emissionreduction targets, by 1997, contributed to a growing consensus around the second condition. Agreement at Kyoto on a universal protocol that included economic instruments such as a market for pollutants to accommodate the market logic favored by the US, individual mandatory emission caps to meet the EU state logic of setting government-led targets, and the exemption of developing countries from binding emission reduction targets-based on the community logic of common but differentiated responsibilities - was facilitated by several mechanisms that promoted consensus on these issues.

These frame shifts illustrate the mechanism of issue linkage, often used for reaching collaborative outcomes in negotiations (Sebenius 1983). Because issues do not exist in a social vacuum, the violation of one agreement carries important repercussions that may extend well beyond the focal issue (Axelrod 1984). Through issue linkage, actors cluster different issues with positive interdependence to open up more possible solutions to such deadlocks (Haas 1980). Linking issues can break deadlocks by gaining actors' commitment on relatively low-priority issues and then getting them to cooperate on high-priority issues (Sebenius 1983). In making such trades, actors typically reframe their rationalefrom seeing an option as a loss to perceiving it as a gain (Elliott et al. 2003).

One of the reasons why the G-77 dropped its fundamental opposition to the use of market-based instruments was the CDM's explicitly stated "win-win" rhetoric around the twin objectives of emission reductions for industrialized countries and accelerated economic development in developing nations through the transfer of green technologies. Also, because climate change was not the highest priority for most G-77 members, they cared little if it failed. In a similar vein, by 1997, the historical contribution of industrialized countries to climate change was clearly highlighted by the IPCC's work (especially its 1995 Second Assessment Report), thereby raising the awareness of these nations that they were contributing to the problem. When it became clear that an agreement was within reach that included binding commitments yet relied on market instruments, the EU-alarmed by the IPCC's Second Assessment Report-was willing to give up its resistance to these policy instruments. Issue linkage was also the likely mechanism that enabled the US to sign the Kyoto Protocol in 1997. The US's introduction of market-based instruments added an issue that reduced the economic costs and increased flexibility for companies, thereby bringing emission reduction targets within more manageable levels. Thus, at that time, the US reframed its previous advocacy of voluntary measures only to the endorsement of binding reduction targets, paving the way for the Kyoto agreement.

We observed active learning as another mechanism that promoted frame shifts in the service of Condition 2. Active learning occurs when new information and evidence or changes in material and discursive conditions prompt actors to rethink the assumptions about the calculus of perceived gains and losses underpinning their logics. For learning to occur, parties' beliefs about causeand-effect relationships must change (Dobbin et al. 2007, Elkins and Simmons 2005). One example is when the EU accepted the proposal of binding emission targets, put on the table by AOSIS negotiators and formally proposed by the US delegation, as an additional possibility to commit historical polluters to action. Another instance is when BP broke ranks with other oil-andgas companies to assume its responsibility for contributing to climate change. The company learned that a proactive climate policy offered substantial cost-saving potential and benefits in terms of goodwill among its constituencies. A third instance was the BASIC group members' shift from eschewing responsibility to 
agreeing that they had become major economic players with high emission levels who had to assume their fair share of the mitigation burden. These countries had learned that their continued economic growth would be compromised without significantly revising their production practices (for instance, through leapfrog energyefficiency improvements), thereby contributing to the global mitigation efforts.

Another mechanism that fostered consensus around the second condition was legitimacy seeking. This mechanism was at least partly responsible for US subnational actors' shifts to unilaterally adopt climate change mitigation policies. In this case, the shifts were toward moral legitimacy, the need to show solidarity with an issue of concern (Franck 1995). Once President Bush declared the Kyoto agreement dead on arrival in the US, many local actors who believed in the adverse effects of climate change were frustrated. Against the backdrop of a climate policy vacuum created by federal inaction, these actors took it upon themselves to initiate mitigation actions. Al Gore's influential documentary and book An Inconvenient Truth framed these in terms of moral convictions: "We all want the same thing: for our children and the generations after them to inherit a clean and beautiful planet capable of supporting a healthy human civilization" (Gore 2006, p. 278). Thus, the internal convictions of many US citizens, local governments, and firms made it morally unacceptable to stand by and do nothing. Instead, they opted for what they believed was "the right thing to do" (Suchman 1995, p. 579). Consequently, convergence around the second condition for a commons logic was driven by several mechanisms: issue linkage, bringing major nation-states on board during the Kyoto negotiations; active learning, enabling actors such as BP and eventually most industrialized countries to change frames in the face of new information; and legitimacy seeking, driving the involvement of progressive companies and US states and citizens.

Condition 3. Forging a working consensus in transnational commons is highly challenging because of the degree of diversity, dispersion, and disparity of actors and their frames in such fields and the lack of an overarching governmental authority to impose top-down regulations. Because one critical component in establishing a new logic within a field is ensuring its governance, Condition 3 needs to be satisfied to ensure the construction of a commons logic. We identified three mechanisms that promoted actors' collective mitigation actions in the climate change field.

First, we identified catalytic amplification, in which actions at lower levels shifted the calculus for higherlevel actors, prompting decisions to move from the corporate to the national to the transnational level, and promoting wider acceptance of a transnational commons logic. Building on Hoffman and Ocasio's (2001) and
Nigam and Ocasio's (2010) idea that events can precipitate field-level shifts, we argue that actors in a field can function as catalyzers who amplify changes in response to the initial precipitating actions through an irreversible chain of events (Hedström and Swedberg 1998). Sewell (1996, p. 871) made a similar observation about the "cascading character of events," which disrupt structures by "touching off dislocations and rearticulations of overlapping or contiguous structures." This mechanism played an important role in the diffusion of mitigation actions, expressly when the initiatives of certain actors catalyzed the actions of others. Our data show a pattern of linkages between BP's decision to adopt a carbontrading scheme, the UK's decision to design a national system for emissions trading, and the EU's adoption of a pan-European scheme. BP's action became one of several factors that prompted the UK to act, and, ultimately, BP served on the Royal Commission that advised the UK on the design of its carbon market. Then, shortly after the opening of the UK's market, the EU, a staunch adversary of market mechanisms, quickly followed suit and launched its own emissions-trading system to regain market control. These decisions, taken together, represent a catalytic process of amplifying influence within the transnational field.

Catalytic amplification also explains why subnational actors in the US launched their own mitigation initiatives despite inaction by the US federal government. Local US actors were inspired to launch localized initiatives because of their involvement in dense transnational social networks. Many local US actors reframed themselves as international actors to lay claim to an international stage and debate. Cities explicitly referenced international emission-reduction norms as contained in the Kyoto Protocol (e.g., the US Mayors Initiative), whereas states localized international norms such as the UK's voluntary $60 \%-70 \%$ reduction targets over 50 years. These local actors were engaging in what Keck and Sikkink (1998, p. 93) referred to as a "boomerang pattern"-influenced by transnational advocacy networks to "walk the talk" and pressurize their (federal) governments.

Second, the mechanism of active learning, identified above, was also conducive to enhanced consensus around the third commons condition. One example, recounted by UNFCCC executive secretary Yvo de Boer, is that the EU, after losing the battle for prescriptive policies and measures, became aware that emission reduction targets could also be realized efficiently through an emissions trading scheme that only specifies the overall target, rather than individual standards for each sector. Another instance is the BASIC countries' pursuit of important energy-efficiency improvements and enhanced reliance on renewable energy carriers to enable sustained economic growth while also containing, at least in relative terms, their greenhouse gas emissions. 
Third, we identified legitimacy seeking, as illustrated by Greenpeace's shift to accepting a largely marketbased climate regime. Although, like most NGOs, Greenpeace initially pressed for a centralized commandand-control approach to regulate emissions, it found itself increasingly isolated in opposing the use of market instruments. Once all other actors, including the EU and G-77 countries, had agreed to the use of market mechanisms, the NGOs were left standing alone. Realizing that the proverbial train had left the station and it was not on it, Greenpeace acquiesced to the less preferred option to avoid being excluded from further discussion. When a majority of powerful actors adopt a controversial practice, it can lose its contentiousness and become normalized as even staunch opponents shift their stances (Briscoe and Safford 2008). In this case, Greenpeace not only changed its frame but also began to promote the positive elements of the plan to preserve its voice in the climate change debate.

An increasing sense of urgency, generated by more extreme weather events and well-publicized messages of elite entrepreneurs (such as Al Gore), has led more and more people not only to view their fates as interconnected but also to perceive their own activities as contributing to climate change. However, despite progress, consensus around the willingness to take collective action to mitigate the damage from further climate change is not yet widespread (see Figure 2). Several key stakeholders (such as the US federal government, many G-77 countries, and conservative firms) are not, or are only marginally, on board. Because the existence and governance of a commons implies collective awareness, responsibility, and action, we argue that a commons logic has gained traction since agreement with these three premises has grown over the period of study, but that consensus about how to and who should take ameliorative action is still elusive in this field.

\section{Discussion}

\section{Socially Constructing Commons}

We provided an account of how a transnational commons logic emerged in the field of climate change. Whereas the study of one type of change in pluralistic institutional fields involves understanding how these fields move from incoherence to relative coherence (Schneiberg and Clemens 2006), the process is more complex in transnational fields. Although debates around a commons logic still persist, we identified some of the key episodes in the field's evolution between 1969 and 2010, when certain actors noticeably changed their frames to enable the emergence of a growing consensus around climate change as a commons problem. Although, arguably, all of our examples do not carry the same weight with respect to their impact on the field because they occurred at different levels (e.g., within
MNCs, NGOs, or (groups of) nations) and involved actors with different degrees of influence, they still provide vital insights into processes by which field frames gain currency and a commons logic emerges in transnational fields.

Three Conditions for Constructing a Commons Logic. Tracking the evolution of the climate change field over four decades enabled us to answer our first research question. Initially, the field's diverse actors operated under the auspices of different institutional governance systems, and each had "a different way of looking at the global reality and global problems and, therefore, a unique approach to them" (Finger 2008, p. 48). These disparate ways of framing climate change included actors viewing it as (1) a false issue, a nonissue, a local issue, or a global issue; (2) an issue for which they bore differential degrees of responsibility (for past, current, or future damage); and (3) one that did or did not require ameliorative action and could be addressed through contrasting approaches. By analyzing the actors' frame shifts over time, we identified three conditions that were gradually embraced by a wide array of actors. We suggest that convergence around these three conditions is necessary for the construction of a transnational commons logic in a field. However, with respect to climate change, over the past 40 years there has been substantial convergence only around the first condition-a sense of a common plight or "positively correlated fate" (Trist 1983, Van Gusteren 1998).

A second stringent condition for the construction of a field as a commons is that actors acknowledge that their own behavior is both a source of and solution to the problem. In the climate change field, this insight began to emerge in 1992 with the UNFCCC. By 2010, there was a fair degree of convergence around this second condition. Thus, unlike the typical social movement framing, in which an external enemy is theorized as a reason to mobilize_- "us against them" (Benford and Snow 2000) - actors in transnational commons must acknowledge their collective complicity, as illustrated by cartoonist Walt Kelly's character Pogo, who asserted, "We have met the enemy and he is us." Collective awareness by actors of their complicity in creating a commons problem and a coincident interpretation of the collective nature of a cause (Fligstein 1997) heightens actors' collective identification with the problem and allows for practices of collaborative engagement. In effect, consensus emerges around the view that a coalition of the whole, or at least of the most powerful actors, is ultimately needed if the problem is to be addressed.

Finally, for a commons logic to gain full force, a third condition must be met: the actors must agree on the collective action required to remedy the problem - that is, what practices are going to be collectively undertaken. Satisfying this condition is a tall order, and full consensus about collective mitigation measures has, so far, 
not been achieved. Because meeting the three conditions involves the collaboration of actors with divergent logics, the commons logic must encompass elements of the underlying logics of key actors. As a result, the transnational commons logic is a hybrid, made up of a variety of core logics such as market, state, profession, and community.

Multiple Mechanisms. In response to our second research question, we have argued that satisfying the three conditions within a field and achieving growing consensus around an emergent commons logic is likely to require a combination of mechanisms to trigger a shift in actors' existing frames. Like Tilly (2001, p. 24), we found that several mechanisms that explain "salient features of episodes or significant differences among them" may operate in conjunction or in succession at different points in time during the field's evolution.

Collective theorization by key institutional entrepreneurs was the mechanism for promoting convergence around the first condition. In the case of climate change, as in many others, exogenous events, also referred to as shocks, jolts, or discontinuities, can play a central role in reconfiguring a field (Hoffman 1999, Meyer 1982). These events create an occasion for theorizing about their causes and consequences and may promote proposals for change (Greenwood et al. 2002). However, events are not inherently disruptive, and their saliency depends on the degree of contestation they may engender (Hoffman and Ocasio 2001, Munir 2005); consequently, not all events lead to institutional transformation. Whereas many studies have focused on institutional entrepreneurship arising from actors on the fringes or outside an organizational field (e.g., Maguire et al. 2004), in this case, "elite actors" (Greenwood and Suddaby 2006) and "high-status players" (Hoffman and Ocasio 2001) promoted change through their social influence and power to flag a potential problem, intensify interest, and catapult it to prominence on the world stage.

To satisfy the second condition, some reconciliation of these frames is needed if actors differ in how they ascribe blame and responsibility for the emerging problem as well as their willingness to take remedial actions. Mechanisms promoting such frame change in our study included issue linkage, active learning, and legitimacy seeking. Actors begin to assume such responsibility when they find ways to link issues to propose possible actions, but others may feel pressured to join the bandwagon, even at the expense of their initial preferences. For instance, the G-77's and EU's acceptance of market instruments (as a result of issue linkage) isolated the environmental movement, which then felt forced to abandon its opposition to market instruments and join the coalition backing the Kyoto agreement to gain pragmatic legitimacy. Other actors (e.g., US states) sought moral legitimacy-accepting responsibility for moral reasons (such as ensuring a viable planet for future generations). With respect to learning, actors such as the BASIC countries learned that they increasingly became part of the problem and needed to assume their fair share of responsibility given the steep uptick in their emissions and the impossibility to sustain growth along businessas-usual trajectories.

Three mechanisms were pivotal in advancing a working consensus around the third condition for a transnational commons logic: active learning, as exemplified by the EU's increasing appreciation of emissions trading as an effective mitigation instrument; legitimacy seeking, as evidenced by Greenpeace's acceptance of market instruments; and catalytic amplification at the field level, in which actions at one level trigger actions at another level, such as measures taken at the corporate, national, and transnational levels to establish a market for carbon trading (e.g., BP, the UK, and the EU, respectively).

Nonlinear Diffusion of Frames and the Emergence of a Transnational Commons Logic. Our third research question focused on how actor-level frame shifts lead to the emergence of a transnational commons logic. Our findings suggest that transnational fields are likely to be characterized by distributed theorization, where actors embrace distinct dimensions of an emergent hybrid logic. Convergence around a commons logic is contingent on different institutional actors with different interests and histories reaching equifinal meaning-that is, coming to at least a minimal level of agreement about what action to take, even if they differ on the reasons for taking the action (Donnellon et al. 1986). The logics held by different actors need not be coincident, but they have to adjust their frames sufficiently to tip the scales toward the emergence of field frames that can eventually lead to the construction of a hybrid commons logic. In our case, the emergence of the first field frame-emphasizing climate change as an anthropogenic, transnational problem-enabled the first condition of a transnational commons logic to be largely satisfied. The rise of the second field frame-promoting binding targets for historical polluters-began to address the second condition. Finally, the emergence of the third, fourth, and fifth field frames-agreeing on and implementing carbon markets as mitigation instruments and taking actions without formal obligations-contributed to the satisfaction of the second and third conditions. Therefore, increasing convergence of actors around the five field-level frames promoted the construction of a transnational commons logic. Our model explains how consensus might emerge through the construction of a hybrid logic embodying different interests, even when actors do not necessarily shift their underlying logics.

This model also differs from fields in which compliance is enforced through discipline or domination. 
Because transnational fields are characterized by the absence of a supranational authority, actors are unlikely to have systemic power or the ability to compel conformity (Djelic and Quack 2008). Rather, agreement depends on negotiation among actors wielding episodic power (Lawrence et al. 2001). Consensus, however, is not an inevitable outcome of negotiations. The diversity and complexity of transnational fields with multiple and distributed sources of theorization creates the potential for conflict among diverse blocking coalitions that may forestall agreements (Lax and Sebenius 1986). However, in instances where an agreement seems imminent, some coalition members may "jump ship" at the last minute, and nonmembers may sign on at the 11th hour, generating discontinuities in the process. Indeed, the way in which frames diffuse in complex transnational fields may, like the weather, be more accurately described as nonlinear (Strang and Soule 1998). Given the interdependencies among actors in a commons, nonlinearity occurs because changes in one location (or level of analysis) within the field are affected by changes in other locations or levels (Purdy and Gray 2009) and may generate unexpected perturbations elsewhere in the field. This can lead to "scale shifts" (Tarrow 2005), prompting other field actors, who embrace different logics, to shift their frames enough to enable the emergence of field frames and the resultant construction of a new, hybrid logic. The EU's and Greenpeace's eventual acceptance of market measures represents such "aboutfaces" in response to actions taken by others. As the negotiating table tipped toward market solutions, the landscape of choices for these actors dramatically narrowed, leading them to subscribe to a less preferred option. Highly contested transnational fields are characterized by "panarchy" and the "Byzantine mishmash" of nonlinear dynamics (Watts 2003, p. 291). Deals among some players can conspire to change the various decision parameters for others. Shifts at lower levels (e.g., within nation-states) can also be prompted by other nations or, conversely, can undermine their own previous national commitments-for instance, declining support for climate change in the US (Klein 2011). Thus, the possibility of backsliding and erosion of agreements also exists. Analyzing how different frames diffuse and converge in transnational fields for the construction of a new logic can, therefore, help identify the dynamics of emergent systems, linking noncontiguous institutions, organizations, and individuals (Detlef 2006).

\section{Broader Theorizing About Commons Construction}

Although our analysis drew on the social construction of a physical or tangible commons, our theorizing also has relevance for the institutionalization of intangible commons, which often span the public-private divide. On the surface, social and natural environments are very different types of systems, operating on vastly different timescales. Yet these systems are interlinked elements of a complex, larger sociotechnical system with simultaneous tendencies toward stability and collapse (Levy and Lichtenstein 2012). Intangible commons include cultural commons such as digital space (e.g., regulation of the Internet; see Bislev and Flyverbom 2008), knowledge commons (e.g., openness of access; see von Hippel and von Krogh 2003), and reputation commons (e.g., spillovers of corporate (in)action; see Barnett and King 2008). As with tangible commons, actions by one firm in intangible commons can threaten the success and survival of other, interconnected firms. This was evidenced by collateral damage to auditing firms in general, not just Arthur Andersen, from the Enron scandal. On the other hand, governance structures for intangible commons also arise despite the risk of free riding, as illustrated by the US chemical industry's voluntary Responsible Care initiative to reduce industrywide harm from the errors of individual firms (Hoffman 1999). Our explanations about the construction of a transnational commons logic and the mechanisms underpinning requisite shifts in frames may inform the origins of these self-regulatory initiatives and other cooperative arrangements forged by businesses and NGOs to certify ethical or sustainable practices.

Our findings also have implications for ongoing tensions between consumers and industry regarding intellectual property rights in the digital commons. With individual free riding evident in widespread online piracy and in the belief that Internet content is free, industries ranging from music to publishing have struggled to capture value from their online offerings. Some of the mechanisms we identified may foster consensus building around the legitimate production and consumption of online content as well as around key obligations and responsibilities in the digital commons. Finally, our insights also have relevance for other types of transnational fields with a sheer complexity of parameters and interests, such as global finance. Calls for a more coordinated transnational, rather than a state-centered, regulation system of global finance, have been growing, especially since the recent financial crisis, which is widely believed to be a systemic failure that began with the advent of an unregulated subprime mortgage market in the US and eventually triggered a global crisis. Some have argued for the need to view global finance as a common pool resource, where different actors-savers, investors, entrepreneurs, and borrowers-are affected by each other's actions, both in the short term and in the long term (Goldin and Vogel 2010). The recent financial crisis has been argued to demonstrate a failure to sustainably govern the "global financial commons" (Barnes 2006, Goldin and Vogel 2010). In the same way as global regulation should limit greenhouse gas emissions, the regulation of global finance has been argued to be a means for limiting "toxic asset" creation, fraud, 
and illegal financial flows, which are widely believed to lead to tragedies. However, when it comes to governing global financial markets, there is no financial regulator or "World Financial Authority" (Eatwell and Taylor 2000) with the powers to set rules like drawing up international accounting standards in the way that the World Trade Organization has the authority to regulate and enforce international law in trade disputes. Instead, sovereign states, ministries, and central banks negotiate among themselves for what they believe to be in their national interest, despite the efforts of the Basel Committee on Banking Supervision to promote voluntary compliance by its members. Because the field of finance is still far away from a shared global approach to addressing financial problems, global finance is a candidate for being a transnational commons, but not yet one. Similarly, a commons logic could potentially emerge in the fields of global waste management, health, and security, characterized by dynamic complexities that link individual, family, community, national, and global levels.

Our theorization thus has broader implications for how transnational issues can come to be constructed as commons, even if the frames that need to change and diffuse might be different from those adopted by the actors with respect to climate change. However, although recursive shocks such as nuclear accidents may catalyze the emergence of a commons logic in a wide range of transnational fields, even these kinds of clarion calls are usually only the first step toward reaching consensus on all three conditions needed for the construction of a commons logic in a field. Indeed, many noncommons fields have made some progress toward being constructed as commons. For example, in strategy and innovation management, scholars and practitioners alike have begun to move away from viewing firms as atomistic entities toward an "ecosystem" perspective that makes interdependencies among firms and their innovations more explicit (Adner 2006).

Although our arguments may hold for many transnational fields, common to these fields is that many actors do not derive their power to mobilize action from the state. However, in local or national contexts, where stakeholder power is more concentrated than diffused, a partial or a higher degree of concerted action may be reached through coercion rather than through negotiation. For example, the Chinese government was able to restrict Google's operations in China. And, at times, even businesses can unilaterally exercise power, such as Walmart forcing its suppliers to adopt certain standards.

Finally, achieving consensus in transnational fields is far from being inevitable. Competition between different and expanding governance constellations that cross over multiple jurisdictions can lead to governance contradictions or even loopholes in polycentric transnational fields (Djelic and Quack 2010) characterized by intractable conflicts (Gray et al. 2007). Tight integration efforts in fields characterized by high levels of diversity and conflict, such as deep and protracted ethnic differences vying for domination, may endanger their very existence and lead to fragmentation and a "distrust spiral" (Djelic and Sahlin-Andersson 2006). Examples could be the Israeli-Palestinian conflict where, even though there is a potential commons, it will take more collective theorization and other mechanisms to produce consensus (peace). National or local identities, practices, prerogatives, and rootedness may be so powerful that they can considerably retard, if not prevent, the construction of a transnational commons logic.

\section{Conclusion}

As global initiatives reduce the importance of national boundaries, new problems emerge that necessitate institutional examination at the transnational level (Djelic and Sahlin-Andersson 2006). Transnational problems, especially those related to commons, pose formidable challenges for business, governmental, and civic leaders globally. Understanding how one such commons has been constructed provides insights for scholars interested in how hybrid logics emerge in transnational settings (Wooten and Hoffman 2008), especially because classic economic formulations of these kinds of fields assert that consensus is highly unlikely without an overarching authority to impose and enforce regulations (Hardin 1968). To portray the global climate commons as a social construction is not to diminish its importance, relevance, or reality (Grundmann and Stehr 2010), but to study how a transnational issue transforms into a commons and why actions may be forestalled.

\section{Contributions}

Our first contribution is to explain how a commons logic is constructed in a transnational field. Drawing on institutional rather than rational models of commons, we offer an alternative explanation for how certain issues come to be constructed as transnational commons, what kinds of mechanisms enable revisions in actors' frames, and how claims about the system or problem diffuse through a field. Institutional accounts deemphasize the exercise of individual agency-privileged in economic models of commons-in favor of agency for other actors-that is, agency shifts from "actorhood to otherhood" (Meyer and Jepperson 2000, p. 107) without necessarily entailing a conflict between self-interest and social values (Parsons 1937). In contrast to conventional economic arguments positing the implausibility of collective governance in the absence of an overarching authority, an institutional perspective offers insights into how field actors, rooted in different institutional logics, create different frames about commons' issues and come to revise their frames in response to others' actions, and how large-scale consensus among dissenting actors 
can emerge to govern commons without such an authority. Thus, an institutional perspective helps explain how social actors ascribe meaning to all kinds of natural (e.g., the atmosphere) and cultural (e.g., the World Wide Web) environments, construct them as commons, and devise collective strategies to govern them.

Second, whereas recent work has theorized the complexity of fields characterized by different and often conflicting institutional pressures and logics (Lounsbury 2007, Pache and Santos 2010, Purdy and Gray 2009), we offer insights into how a new logic is constructed and changes the "rules of the game"-a task that North (1990) suggested is particularly suited to institutional analysis. We identified three distinct conditions for the construction of a commons logic: building agreement around the interconnectedness of actor fates related to a commons, admitting collective complicity in creating the commons problem rather than externalizing it to others, and sharing understanding of how to jointly address the problem. Current depictions of framing and mobilization offered by social movement and institutional scholars typically portray actors as aggrieved victims of societal injustices, making clear distinctions between victims and perpetrators. Instead, in transnational commons, the focus of framing is to implicate actors as collectively responsible for the problem and its solutions-that is, as perpetrators, victims, and saviors.

Third, building on the work of Nigam and Ocasio (2010) and Liu et al. (2012), we identified several mechanisms that precipitate microrevisions in actors' frames, leading at times to the emergence of wider consensus around the commons logic among dissenting actors in transnational fields without necessitating identical theorizations and interpretations. We linked these into a process model, depicting their importance in satisfying different conditions for the emergence of a commons logic. Coincident behavioral implications, rather than coincident interpretations, may suffice for collective action (Donnellon et al. 1986).

Fourth, classic models of diffusion, both relational and cultural (Strang and Soule 1998), do not sufficiently capture the interdependencies among different, concatenated actors that are inherent in complex transnational fields as various frames diffuse. In these fields, domestic and international concerns fuse, interactions transcend national borders, and horizontal and vertical relations between state and non-state actors at international, national, and subnational levels create new opportunities for collective action, as seen in global protests such as the 1999 "Battle of Seattle" (Tarrow 2005). The diffusion of different frames and counterframes as the climate commons was being constructed suggests that a nonlinear model of diffusion is at play in transnational settings. Unlike linear models, in which social frames spread through established networks (Strang and Soule 1998), nonlinear diffusion is like a "thousand points of light," characterized by a wide range of scales and constituents, unanticipated perturbations, discontinuities, and catalytic amplifications (Tarrow 2005).

\section{Future Research}

Although actors in transnational fields may engage in collective action to produce negotiated agreements, they may fail to establish sustainable norms and practices in the structuration phase of institutionalization. Thus, consensus in itself is not a "closing act" for institutionalization (Lawrence et al. 2001). Future work could address the sustainability and disruption of consensus in transnational fields. Additionally, it is important to develop an understanding about what institutional leadership in transnational commons fields might entail. Given the wide array of actors and competing logics, distributed forms of leadership (Gronn 2002) may hold promise. Finally, institutional scholars may turn to complexity theory for insights into climate change (Ansari et al. 2011) and other possible tragedies of transnational commons. Complexity theory examines nonlinear dynamics and emphasizes the limits to predictability (Bolton and Mitleton-Kelly 2010, Levy and Lichtenstein 2012). Clearly, understanding and acting to avert the tragedy of the commons requires robust theorizing that captures the complexity of the fields under consideration.

\section{Acknowledgments}

All authors contributed equally to this article. They greatly benefited from the constructive feedback by senior editor William Ocasio and three anonymous Organization Science reviewers. They are grateful to Martin Kilduff, Jonathan Pinto, Henri Schildt, Marc Ventresca, and others at the Organization Theory Research Group (OTREG) seminar at Imperial College Business School. The authors also thank the participants at the Organizations Research Group (ORG) seminar at the Smeal College of Business, Pennsylvania State University, as well as Peer Fiss, Santi Furnari, and Juliane Reinecke for their insightful comments on earlier versions of this manuscript.

\section{Endnotes}

${ }^{1}$ Following Thornton et al. (2012), we have subsumed the environmental logic under a community logic, because many of the underlying principles of a community logic apply (for instance, the premise of interconnectedness). However, whereas a community logic hinges on social connections, an environmental logic goes beyond this to acknowledge and highlight connections between humans and the natural environment. Convincing arguments supporting the existence of a distinct environmental (green) logic (Boltanski and Thévenot 2006, Frank et al. 2000) and a sustainability logic (Dienhart 2010) have also been made.

${ }^{2}$ We adopt a "distributed" view of institutional entrepreneurship, emphasizing the collective dimension of the institutionalization process (Lounsbury and Crumley 2007, Wijen and Ansari 2007).

${ }^{3}$ The 1970 Study of Critical Environmental Problems and the 1971 Study of Man's Impact on Climate were hallmark publications coordinated by Wilson. 
${ }^{4}$ However, according to our interviews, other actors noted BP backsliding on its commitment to renewable energy. BP terminated its membership in the proactive US Climate Action Partnership in 2010 (Power and Casselman 2010) and continues donating to the climate-skeptic trade association American Petroleum Industry (Macalister 2009).

${ }^{5}$ We use the term "recursive" because some shocks may be the long-term results of human actions (such as an increase in adverse weather conditions due to human-induced climate change or a financial crisis caused by actors flooding the market with junk bonds). The underlying assumption is that social conduct can both alter and be altered by natural processes (Grundmann and Stehr 2010), just like social structure is both the medium and the outcome of the events that transpire (Giddens 1979, Hoffman and Ocasio 2001).

\section{References}

Abbott A (1990) A primer on sequence methods. Organ. Sci. 1(4):375-392.

Adner R (2006) Match your innovation strategy to your innovation ecosystem. Harvard Bus. Rev. 84(4):98-107.

Ahrne G, Brunsson N (2006) Organizing the world. Djelic M-L, Sahlin-Andersson K, eds. Transnational Governance: Institutional Dynamics of Regulation (Cambridge University Press, Cambridge, UK), 74-94.

Ansari S, Fiss P, Zajac E (2010) Made to fit: How practices vary as they diffuse. Acad. Management Rev. 35(1):67-92.

Ansari S, Gray B, Wijen F (2011) Fiddling while the ice melts? How organizational scholars can take a more active role in the climate change debate. Strategic Organ. 9(1):70-76.

Axelrod R (1984) The Evolution of Cooperation (Basic Books, New York).

Bäckstrand K, Lövbrand E (2007) Climate governance beyond 2012: Competing discourses of green governmentality, ecological modernization and civic environmentalism. Pettenger ME, ed. The Social Construction of Climate Change: Power, Knowledge, Norms, Discourses (Ashgate, Aldershot, UK), 123-148.

Banerjee AV (1992) A simple model of herd behavior. Quart. J. Econom. 107(3):797-818.

Barley SR (1990) The alignment of technology and structure through roles and networks. Admin. Sci. Quart. 35(1):61-103.

Barnes P (2006) Capitalism 3.0: A Guide to Reclaiming the Commons (Barret-Koehler, San Francisco).

Barnett M, King A (2008) Good fences make good neighbors: A longitudinal analysis of an industry self-regulation institution. Acad. Management J. 51(6):1150-1170.

Barrett S (2003) Environment and Statecraft: The Strategy of Environmental Treaty-Making (Oxford University Press, Oxford, UK).

Battilana J, Dorado S (2010) Building sustainable hybrid organizations: The case of commercial microfinance organizations. Acad. Management J. 53(6):1419-1440.

Benford R, Snow D (2000) Framing processes and social movements: An overview and assessment. Annual Rev. Sociol. 26:611-639.

Berger P, Luckman T (1968) The Social Construction of Reality: A Treatise in the Sociology of Knowledge (Anchor Books, Garden City, NY).

Best J (2001) Social progress and social problems: Toward a sociology of gloom. Sociol. Quart. 42(1):1-12.
Bislev S, Flyverbom M (2008) Transnational private governance of the Internet: The roles of business. Graz J-C, Nolke A, eds. Transnational Private Governance and Its Limits (Routlgedge, London), 129-141.

Blomley N (2008) Enclosure, common right and the property of the poor. Soc. Legal Stud. 17(3):311-331.

Blumer H (1971) Social problems as collective behavior. Soc. Problems 18(3):298-306.

Boltanski L, Thévenot L (2006) On Justification: Economies of Worth (Princeton University Press, Princeton, NJ).

Bolton J, Mitleton-Kelley E (2010) Policy and climate change. Emergence: Complexity Organ. 12(2):1-6.

Briscoe F, Safford S (2008) The Nixon-in-China effect: Activism, imitation, and the institutionalization of contentious practices. Admin. Sci. Quart. 53(3):460-491.

Coleman J (1974) Power and the Structure of Society (W. W. Norton, New York).

Creed D, Langstraat JA, Scully MA (2002) A picture of the frame: Frame analysis as technique and as politics. Organ. Res. Methods 5(1):34-55.

Darley J, Latané B (1968) Bystander intervention in emergencies: Diffusion of responsibility. J. Personality Soc. Psych. 8(4):377-383.

Davis GF, Marquis C (2005) Prospects for organization theory in the early twenty-first century: Institutional fields and mechanisms. Organ. Sci. 16(4):332-343.

Demeritt D (2001) The construction of global warming and the politics of science. Ann. Assoc. Amer. Geographers 91(2):307-337.

Depledge J (2005) The Organization of Global Negotiations: Constructing the Climate Change Regime (Earthscan, London).

Detlef J (2006) Globalisation as "Galton's problem": The missing link in the analysis of diffusion patterns in welfare state development. Internat. Organ. 60(2):401-431.

Dienhart J (2010) Sustainability, cross-sector collaboration, institutions, and governance. Bus. Ethics Quart. 20(4):725-728.

DiMaggio PJ (1991) Constructing an organizational field as a professional project: U.S. art museums, 1920-1940. Powell WW, DiMaggio PJ, eds. The New Institutionalism in Organizational Analysis (University of Chicago Press, Chicago), 267-292.

Djelic M-L, Quack S (2008) Institutions and transnationalization. Greenwood R, Oliver C, Sahlin K, Suddaby R, eds. The Sage Handbook of Organizational Institutionalism (Sage, London), 299-324.

Djelic M-L, Quack S (2010) Transnational Communities: Shaping Global Economic Governance (Cambridge University Press, Cambridge, UK).

Djelic M-L, Sahlin-Andersson K (2006) Introduction: A world of governance: The rise of transnational regulation. Djelic M-L, Sahlin-Andersson K, eds. Transnational Governance: Institutional Dynamics of Regulation (Cambridge University Press, Cambridge, UK), 1-29.

Dobbin F, Simmons B, Garrett G (2007) The global diffusion of public policies: Social construction, coercion, competition or learning? Annual Rev. Sociol. 33:449-472.

Donnellon A, Gray B, Bougon MG (1986) Communication, meaning, and organized action. Admin. Sci. Quart. 31(1):43-55.

Douglas M (1986) How Institutions Think (Syracuse University Press, Syracuse, NY).

Drucker-Godard C, Ehlinger S, Grenier C (1999) Validity and reliability. Thiétart RA, ed. Doing Management Research: A Comprehensive Guide, Chapter 10 (Sage, London). 
Eatwell J, Taylor L (2000) Global Finance at Risk: The Case for International Regulation (Polity Press, Cambridge, UK).

Elkins Z, Simmons B (2005) On waves, clusters, and diffusion: A conceptual framework. Ann. Amer. Acad. Political Soc. Sci. 598(1):33-51.

Elliott M, Gray B, Lewicki RJ (2003) Lessons learned about the framing and reframing of intractable environmental conflicts. Lewicki RJ, Gray B, Elliott M, eds. Making Sense of Intractable Environmental Conflicts: Concepts and Cases (Island Press, Washington, DC), 409-436.

Elsbach KD, Sutton RI (1992) Acquiring organizational legitimacy through illegitimate actions: A marriage of institutional and impression management theories. Acad. Management $J$. 35(4):699-738.

Emirbayer M, Mische A (1998) What is agency? Amer. J. Sociol. 103(4):962-1023.

Engels A (2006) Market creation and transnational rule-making: The case of $\mathrm{CO}_{2}$ emission trading. Djelic M-L, Sahlin-Andersson K, eds. Transnational Government: Institutional Dynamics of Regulation (Cambridge University Press, Cambridge, UK), 329-348.

Fehr E, Gintis H (2007) Human motivation and social cooperation: Experimental and analytical foundations. Annual Rev. Sociol. 33:43-64.

Finger M (2008) Which governance for sustainable development? An organizational and institutional perspective. Park J, Conca K, Finger M, eds. The Crisis of Environmental Governance: Towards a New Political Economy of Sustainability (Routledge, Oxford, UK), 34-57.

Fiss P, Hirsch P (2005) The discourse of globalization: Framing and sensemaking of an emerging concept. Amer. Sociol. Rev. 70(1):29-52.

Fligstein N (1997) Social skill and institutional theory. Amer. Behavioral Scientist 40(4):397-405.

Franck T (1995) Fairness in International Law and Institutions (Oxford University Press, New York).

Frank DJ, Hironaka A, Schofer E (2000) The nation-state and the natural environment over the twentieth century. Amer. Sociol. Rev. 65(1):96-116.

Friedland R, Alford R (1991) Bringing society back in: Symbols, practices, and institutional contradictions. Powell WW, DiMaggio PJ, eds. The New Institutionalism in Organizational Analysis (University of Chicago Press, Chicago), 232-263.

Garud R (2008) Conferences as venues for the configuration of emerging organizational fields: The case of cochlear implants. J. Management Stud. 45(6):1061-1088.

Giddens A (1979) Central Problems in Social Theory: Action, Structure and Contradiction in Social Analysis (Macmillan, London).

Glasbergen P, Biermann F, Mol A, eds. (2007) Partnerships, Governance and Sustainable Development: Reflections on Theory and Practice (Edward Elgar, Cheltenham, UK).

Glynn MA, Lounsbury M (2005) From the critics' corner: Logic blending, discursive change and authenticity in a cultural production system. J. Management Stud. 42(5):1031-1055.

Goldin I, Vogel T (2010) Global governance and systemic risk in the 21st century: Lessons from the financial crisis. Global Policy $1(1): 4-15$.

Gore A (2006) An Inconvenient Truth: The Planetary Emergency of Global Warming and What We Can Do About It (Rodale, New York).
Gray B (2003) Framing of environmental disputes. Lewicki R, Gray B, Elliott M, eds. Making Sense of Intractable Environmental Conflicts: Concepts and Cases (Island Press, Washington, DC), 11-34.

Gray B, Coleman P, Putnam L (2007) Intractable conflicts: New perspectives on the causes and conditions for change. Amer. Behavioral Scientist 50(11):1415-1429.

Greenwood R, Suddaby R (2006) Institutional entrepreneurship in mature fields: The big five accounting firms. Acad. Management J. 49(1):27-48.

Greenwood R, Suddaby R, Hinings B (2002) Theorizing change: The role of professional associations in the transformation of institutionalized fields. Acad. Management J. 45(1):58-80.

Gronn P (2002) Distributed leadership as a unit of analysis. Leadership Quart. 13(4):423-451.

Gross N (2009) A pragmatist theory of social mechanisms. Amer. Sociol. Rev. 74(3):358-379.

Grubb M, Vrolijk C, Brack D (1999) The Kyoto Protocol: A Guide and Assessment (Royal Institute of International Affairs, London).

Grundmann R, Stehr N (2010) Climate change: What role for sociology?: A response to Constance Lever-Tracy. Current Sociol. 58(6):897-910.

Haas EB (1980) Why collaborate? Issue-linkage and international regimes. World Politics 32(3):347-405.

Hardin G (1968) The tragedy of the commons. Science 162(3859): 1243-1248.

Hardin G (1998) Extensions of "the tragedy of the commons." Science 280(5364):682-683.

Hardy C, Maguire S (2010) Discourse, field-configuring events, and change in organizations and institutional fields: Narratives of DDT and the Stockholm Convention. Acad. Management J. 53(6):1365-1392.

Hart D, Victor D (1993) Scientific elites and the making of US policy for climate change research, 1957-74. Soc. Stud. Sci. 23(4):643-680.

Härtel C, Pearman GI (2010) The climate change issue: The role for behavioral sciences in understanding and responding. J. Management Organ. 16(1):16-47.

Haveman HA, Rao H (1997) Structuring a theory of moral sentiments: Institutional and organizational coevolution in the early thrift industry. Amer. J. Sociol. 102(6):1606-1651.

Heckathorn D (1996) The dynamics and dilemmas of collective action. Amer. Sociol. Rev. 61(2):250-277.

Hedström P, Swedberg R (1998) Social mechanisms: An introductory essay. Hedström P, Swedberg R, eds. Social Mechanisms: An Analytical Approach to Social Theory (Cambridge University Press, Cambridge, UK), 1-31.

Heggelund G, Buan I (2009) China in the Asia-Pacific partnership: Consequences for UN climate change mitigation efforts? Internat. Environ. Agreements: Politics, Law Econom. 9(3):301-317.

Hoffman AJ (1999) Institutional evolution and change: Environmentalism and the U.S. chemical industry. Acad. Management $J$. 42(4):351-371.

Hoffman AJ, Ocasio W (2001) Not all events are attended equally. Toward a middle-range theory of industry attention to external events. Organ. Sci. 12(4):414-434.

Holder J, Flessas T (2008) Emerging commons. Soc. Legal Stud. 17(3):299-310.

Holm P (1995) The dynamics of institutionalization: Transformation processes in Norwegian fisheries. Admin. Sci. Quart. 40(3): $398-422$. 
Intergovernmental Panel on Climate Change (1995) Climate change 1995: Second assessment report. Report, Intergovernmental Panel on Climate Change, Geneva.

Intergovernmental Panel on Climate Change (2007) Climate change 2007: Synthesis report. Report, Intergovernmental Panel on Climate Change, Geneva.

Kaplan S (2008) Framing contests: Strategy making under uncertainty. Organ. Sci. 19(5):729-752.

Keck M, Sikkink K (1998) Activists Beyond Borders: Advocacy Networks in International Politics (Cornell University Press, Ithaca, NY).

Klein N (2011) Capitalism vs. the climate. Nation 293(22):12-21.

Kolk A, Pinkse J (2007) Multinationals' political activities on climate change. Bus. Soc. 46(2):201-228.

Krasner SD (1991) Global communications and national power: Life on the Pareto frontier. World Politics 43(3):336-366.

Langley A (1999) Strategies for theorizing from process data. Acad. Management Rev. 24(4):691-710.

Lawrence T, Winn M, Jennings P (2001) The temporal dynamics of institutionalization. Acad. Management Rev. 26(4):624-644.

Lax D, Sebenius J (1986) The Manager as Negotiator: Bargaining for Cooperation and Competitive Gain (Free Press, New York).

Leblebici H, Salancik GR, Copay A, King T (1991) Institutional change and the transformation of interorganizational fields: An organizational history of the U.S. radio broadcasting industry. Admin. Sci. Quart. 36(3):333-363.

Leggett J (1999) The Carbon War: Dispatches from the End of the Oil Century (Allen Lane, London).

Levy D, Egan D (2003) A neo-Gramscian approach to corporate political strategy: Conflict and accommodation in the climate change negotiations. J. Management Stud. 40(4):803-829.

Levy D, Kolk K (2002) Strategic responses to global climate change: Conflicting pressures on multinationals in the oil industry. Bus. Politics 4(3):275-300.

Levy DL, Lichtenstein BB (2012) Approaching business and the environment with complexity theory. Bansal P, Hoffman AJ, eds. The Oxford Handbook of Business and the Environment (Oxford University Press, Oxford, UK), 591-610.

Levy MA, Keohane RO, Haas PM (1993) Improving the effectiveness of international environmental institutions. Haas PM, Keohane RO, Levy MA, eds. Institutions for the Earth: Sources of Effective International Environmental Protection (MIT Press, Cambridge, MA), 397-426.

Liu LA, Friedman RA, Barry B, Gelfand MJ, Zhang Z-X (2012) The dynamics of consensus building in intracultural and intercultural negotiations. Admin. Sci. Quart. 57(2):269-304.

Lounsbury M (2007) A tale of two cities: Competing logics and practice variation in the professionalizing of mutual funds. Acad. Management J. 50(2):289-307.

Lounsbury M, Crumley E (2007) New practice creation: An institutional perspective on innovation. Organ. Stud. 28(7):993-1012.

Lounsbury M, Ventresca M, Hirsch PM (2003) Social movements, field frames and industry emergence: A cultural-political perspective on US recycling. Socio-Econom. Rev. 1(1):71-104.

Macalister T (2009) BP and Shell warned to halt campaign against US climate change bill. Guardian (August 19) http://www .guardian.co.uk/business/2009/aug/19/oil-firms-warned-over-uslobbying.
Maguire S, Hardy C (2006) The emergence of new global institutions: A discursive perspective. Organ. Stud. 27(1):7-29.

Maguire S, Hardy C (2009) Discourse and deinstitutionalization: The decline of DDT. Acad. Management J. 52(1):148-178.

Maguire S, Hardy C, Lawrence T (2004) Institutional entrepreneurship in emerging fields: HIV/AIDS treatment advocacy in Canada. Acad. Management J. 47(5):657-679.

Mann ME, Kump LR (2008) Dire Predictions: Understanding Global Warming (DK Publishing, New York).

Margolick RM, Russell D (2001) Corporate Greenhouse Gas Reduction Targets (Pew Center on Global Climate Change, Arlington, VA).

Mars MM, Lounsbury M (2009) Raging against or with the private marketplace? Logic hybridity and eco-entrepreneurship. J. Management Inquiry 18(1):4-13.

Martin J (2003) What is field theory? Amer. J. Sociol. 109(1):1-49.

McCright AM, Dunlap RE (2000) Challenging global warming as a social problem: An analysis of the conservative movement's counter-claims. Soc. Problems 47(4):499-522.

Meyer AD (1982) Adapting to environmental jolts. Admin. Sci. Quart. 27(4):515-537.

Meyer J, Jepperson R (2000) The "actors" of modern society: Cultural rationalization and the ongoing expansion of social agency. Sociol. Theory 18(1):100-120.

Misangyi V, Weaver G, Elms H (2008) The interplay among institutional logics, resources, and institutional entrepreneurs. Acad. Management Rev. 33(3):750-770.

Munir K (2005) The social construction of events: A study of institutional change in the photographic field. Organ. Stud. 26(1): 93-112.

New York Times, The (2007) China overtakes U.S. in greenhouse gas emissions. (June 20) http://www.nytimes.com/2007/06/20/ business/worldbusiness/20iht-emit.1.6227564.html.

Nigam A, Ocasio W (2010) Event attention, environmental sensemaking, and change in institutional logics: An inductive analysis of the effects of public attention to Clinton's health care reform initiative. Organ. Sci. 21(4):823-841.

North D (1990) Institutions, Institutional Change and Economic Performance (Cambridge University Press, Cambridge, UK).

Oberthür S, Ott H (1999) The Kyoto Protocol: International Climate Policy for the 21st Century (Springer-Verlag, Berlin).

Olson M (1965) The Logic of Collective Action: Public Goods and the Theory of Groups (Harvard University Press, Cambridge, MA).

Ostrom E (1990) Governing the Commons: The Evolution of Institutions for Collective Action (Cambridge University Press, Cambridge, UK).

Ostrom E, Burger J, Field CB, Norgaard RB, Policansky D (1999) Revisiting the commons: Local lessons, global challenges. Science 284(5412):278-282.

Ott HE, Sterk W, Watanabe R (2008) The Bali roadmap: New horizons for global climate policy. Climate Policy 8(1):91-95.

Pache A, Santos F (2010) When worlds collide: The internal dynamics of organizational responses to conflicting institutional demands. Acad. Management Rev. 35(3):455-476.

Parsons T (1937) The Structure of Social Action (Free Press, New York).

Pentland B (1999) Building process theory with narrative: From description to explanation. Acad. Management Rev. 24(4): 711-724. 
Pettenger ME, ed. (2007) The Social Construction of Climate Change: Power, Knowledge, Norms, Discourses (Ashgate, Aldershot, UK).

Pew Center on Global Climate (2010) Cumulative $\mathrm{CO}_{2}$ emissions (1850-2000). Accessed June 7, 2011, http://www.pewclimate .org/facts-and-figures/international/cumulative.

Pinkse J, Kolk A (2009) International Business and Global Climate Change (Routledge, Oxford, UK).

Power S, Casselman B (2010) Defections shake up climate coalition. Wall Street Journal (February 17) http://online.wsj.com/article/ SB10001424052748704804204575069440096420212.html.

Pulver S (2007) Making sense of corporate environmentalism: An environmental contestation approach to analyzing the causes and consequences of the climate change policy split in the oil industry. Organ. Environ. 20(1):44-83.

Purdy J, Gray B (2009) Conflicting logics, mechanisms of diffusion and multilevel dynamics in emerging institutional fields. Acad. Management J. 52(2):355-380.

Rao H, Giorgi S (2006) Code breaking: How entrepreneurs exploit cultural logics to generate institutional change. Res. Organ. Behav. 27:269-304.

Rao V, Appadurai A (2008) Scale and mobility in defining the commons. Bardhan P, Ray I, eds. The Contested Commons: Conversations Between Economists and Anthropologists (Blackwell, Malden, MA), 159-167.

Reay T, Hinings CR (2009) Managing the rivalry of competing institutional logics. Organ. Stud. 30(6):629-652.

Rosenau JN (1992) Governance, order, and change in world politics. Rosenau JN, Czempiel E-O, eds. Governance Without Government: Order and Change in World Politics (Cambridge University Press, Cambridge, UK), 1-29.

Rudel TK, Roberts JT, Carmin J (2011) Political economy of the environment. Annual Rev. Sociol. 37:221-238.

Rydin Y (2003) Conflict, Consensus and Rationality in Environmental Planning: An Institutional Discourse Approach (Oxford University Press, Oxford, UK).

Sandler T (2004) Global Collective Action (Cambridge University Press, Cambridge, UK).

Sands P, Peel J (2005) Environmental protection in the twenty-first century: Sustainable development and international law. Axelrod RS, Downie DL, Vig NJ, eds. The Global Environment: Institutions, Law and Policy, 2nd ed. (CQ Press, Washington, DC), 43-63.

Schelling T (1978) Micromotives and Macrobehavior (W. W. Norton, New York).

Schnaiberg A (1980) The Environment: From Surplus to Scarcity (Oxford University Press, New York).

Schneiberg M, Clemens E (2006) The typical tools for the job: Research strategies in institutional analysis. Sociol. Theory 24(3): 195-227.

Scott R (1995) Institutions and Organizations, 2nd ed. (Sage, Thousand Oaks, CA).

Sebenius J (1983) Negotiation arithmetic: Adding and subtracting issues and parties. Internat. Organ. 37(2):281-316.

Seo M-G, Creed D (2002) Institutional contradictions, praxis, and change: A dialectical perspective. Acad. Management Rev. 27(2): 222-247.

Sewell WH (1996) Historical events as transformations of structures: Inventing revolution at the Bastille. Theory Soc. 25(6):841-881.
Snow DA, Rochford EB Jr, Worden SK, Benford RD (1986) Frame alignment processes, micromobilization, and movement participation. Amer. Sociol. Rev. 51(4):464-481.

Steinberg P (2001) Social Construction of the Ocean (Cambridge University Press, Cambridge, UK).

Strang D, Soule S (1998) Diffusion in organizations and social movements: From hybrid corn to poison pills. Annual Rev. Sociol. 24:265-290.

Suchman MC (1995) Managing legitimacy: Strategic and institutional approaches. Acad. Management Rev. 20(3):571-610.

Suddaby R, Greenwood R (2005) Rhetorical strategies of legitimacy. Admin. Sci. Quart. 50(1):35-67.

Tarrow S (2005) The New Transnational Activism: Cambridge Studies in Contentious Politics (Cambridge University Press, Cambridge, UK).

Thornton P, Ocasio W (1999) Institutional logics and the historical contingency of power in organizations: Executive succession in the higher education publishing industry, 1958-1990. Amer. J. Sociol. 105(3):801-843.

Thornton PH, Ocasio W (2008) Institutional logics. Greenwood R, Oliver C, Sahlin K, Suddaby R, eds. The Sage Handbook of Organizational Institutionalism (Sage, Thousand Oaks, CA), 99-129.

Thornton P, Ocasio W, Lounsbury M (2012) The Institutional Logics Perspective: A New Approach to Culture, Structure and Process (Oxford University Press, New York)

Tilly C (2001) Mechanisms in political processes. Annual Rev. Political Sci. 4:21-41.

Trist E (1983) Referent organizations and the development of interorganizational domains. Human Relations 36(3):247-268.

UN Framework Convention on Climate Change (2009) Kyoto Protocol: Status of ratification. Accessed July 24, 2009, http:// unfecc.int/files/kyoto_protocol/status_of_ratification/application/ pdf/kp_ratification.pdf.

Uri S, Bearman PS (2010) The temporal structure of scientific consensus formation. Amer. Sociol. Rev. 75(6):817-840.

US Environmental Protection Agency (2003) Global warming: State actions list. Accessed June 17, 2009, http://yosemite.epa.gov/ globalwarming/ghg.nsf/StatePolicyOptionsSearch?openform.

Van de Ven AH, Poole MS (2002) Field research methods. Baum JAC, ed. The Blackwell Companion to Organizations (Oxford University Press, New York), 867-888.

Van Gusteren H (1998) A Theory of Citizenship: Organizing Plurality in Contemporary Democracies (Westview, Boulder, CO).

Van Laerhoven F, Ostrom E (2007) Traditions and trends in the study of the commons. Internat. J. Commons 1(1):3-28.

Vogel D, Toffel M, Post D, Aragon NU (2012) Environmental federalism in the European Union and the United States. Wijen F, Zoeteman K, Pieters J, van Seters P, eds. A Handbook of Globalisation and Environmental Policy: National Government Interventions in a Global Arena, 2nd ed. (Edward Elgar, Cheltenham, UK), 321-361.

von Hippel E, von Krogh G (2003) Open source software and the "private-collective" innovation model: Issues for organization science. Organ. Sci. 14(2):209-223.

Watts D (2003) Six Degrees: The Science of a Connected Age (W. W. Norton, New York).

Weber M, Kopelman S, Messick D (2004) A conceptual review of decision making in social dilemmas: Applying the logic of appropriateness. Personality Soc. Psych. Rev. 8(3):281-307. 
Wejnert B (2002) Integrating models of diffusion of innovations: A conceptual framework. Annual Rev. Sociol. 28:297-326.

Wijen F, Ansari S (2007) Overcoming inaction through collective institutional entrepreneurship: Insights from regime theory. Organ. Stud. 28(7):1079-1100.

Wooten M, Hoffman AJ (2008) Organizational fields: Past, present and future. Greenwood R, Oliver C, Suddaby R, Sahlin K, eds. The Sage Handbook of Organizational Institutionalism (Sage, London), 130-148.

Young O (1994) International Governance: Protecting the Environment in a Stateless Society (Cornell University Press, Ithaca, NY).

Shahzad (Shaz) Ansari is a Reader (associate professor) at the Judge Business School, University of Cambridge, and a visiting assistant professor at the Rotterdam School of Management, Erasmus University Rotterdam. He received his Ph.D. from the University of Cambridge. He serves on the editorial boards of the Academy of Management Review,
Organization Science, Journal of Management Studies, and Organization Studies. His research interests include institutional change, innovation management, and new markets.

Frank Wijen is an associate professor of strategic management at Rotterdam School of Management, Erasmus University Rotterdam. He holds a Ph.D. in management from Tilburg University. His research interests include institutional processes, organizational learning, influence and power, and globalization, applied to issues of environmental governance and sustainable development.

Barbara Gray is a professor of organizational behavior, Executive Programs Faculty Fellow, and director of the Center for Research in Conflict and Negotiation at Pennsylvania State University. She received her Ph.D. from Case Western Reserve University. She has published numerous articles and books on topics such as multiparty collaborative alliances and partnerships, organizational and interorganizational conflict, intercultural and interdisciplinary team dynamics, framing, and institutional logics. 